\title{
Sau reservoir's light climate: relationships between Secchi depth and light extinction coefficient
}

\author{
J. Armengol ${ }^{1}$, L. Caputo ${ }^{1}$, M. Comerma ${ }^{1}$, C. Feijoó ${ }^{1,2}$, J.C. García ${ }^{1,3}$, R. Marcé1, \\ E. Navarro and J. Ordoñez ${ }^{1}$
}

${ }^{1}$ Dept. Ecología. Fac. Biología. Univ. de Barcelona. Avd. Diagonal, 645. 08028-Barcelona. Spain. jarmengol@ub.edu

${ }^{2}$ Programa de Investigaciones en Ecología Acuática. Univ. Nacional de Luján. CC 221. 6700-Luján. Argentina.

${ }^{3}$ Aigües Ter-Llobregat. Ctra. Martorell a Olesa, km 4.6. 08630-Abrera. Barcelona. Spain

\begin{abstract}
SUMMARY
The relationship between light extinction coefficient $\left(\mathrm{k}_{\mathrm{T}}\right)$ and Secchi depth $\left(\mathrm{Z}_{\mathrm{SD}}\right)$, as well as that between these variables and chlorophyll- $a$ concentration (chl-a) and suspended material $\left(\mathrm{SS}_{\mathrm{T}}\right)$ was studied in the Sau reservoir between 1995 and 2001. The results show that $\mathrm{k}_{\mathrm{T}}$ and $\mathrm{Z}_{\mathrm{SD}}$ are correlated by the equation $\mathrm{k}_{\mathrm{T}}=1.36 \mathrm{Z}_{\mathrm{SD}}{ }^{-0.806}$, although this relationship exhibits a high inter-annual variability. Among the different factors contributing to water transparency, $\mathrm{SS}_{\mathrm{T}}$ is the most correlated variable with both $\mathrm{k}_{\mathrm{T}}$ and $\mathrm{Z}_{\mathrm{SD}}$. On the other hand, chl- $a$ showed a weak or no correlation, either when the whole studied period was analyzed or, for most years, when they were considered individually. The cause of this low contribution of chl- $a$ to water transparency is to be found in the large amount of detritic matter present in Sau, due both to the inputs of allochthonous particulate organic matter, as well as sediment mobilization from the bottom or the shores during the dry periods. For the period from May 2000 through December 2001, a partition of $k_{T}$ and $Z_{S D}$ was performed using the multiple regression method to assess the contribution of the several dissolved and particulate components. The considered variables were chlorophyll-a, detritic particulate organic matter, inorganic matter, and phytoplankton as particulate material, as well as the effect of water. The results show that detritic particulate matter, with a contribution that ranges from $11 \%$ to $63.5 \%$ of $\mathrm{k}_{\mathrm{T}}$ and from $20.3 \%$ to $86 \%$ of $Z_{\mathrm{SD}}$, is the most important factor influencing water transparency. This results show that the diffuse irradiance is much more important than the directional or vectorial one, and that therefore, Secchi depth is a good descriptor of the light climate, but not of chlorophyll- $a$ concentration.
\end{abstract}

Keywords: Secchi depth, light extinction coefficient, water transparency, chlorophyll- $a$, suspended solids, tripton, inorganic matter

\section{RESUMEN}

En el embalse de Sau se ha estudiado la relación existente entre el coeficiente de extinción de la luz (kT) y la profundidad de visión del disco de Secchi $\left(Z_{S D}\right)$ así como entre dichas variables y la concentración de clorofila a (chl-a) y material particulado $\left(S S_{T}\right)$ entre 1995 y 2001. Los resultados obtenidos muestran que $k_{T}$ y $Z_{S D}$ están relacionadas mediante la ecuación $k_{T}=1.36 Z_{S D}-0.806$ si bien hay una elevada variabilidad interanual en la relación entre ambas. De los diferentes factores que intervienen en la transparencia del agua, $S S_{T}$ es la variable más correlacionada, tanto con $k_{T}$ como con $Z_{S D}$. Por el contrario, chl-a muestra poca o nula correlación tanto para todo el periodo estudiado, como para la mayoría de los años considerados de forma individual. La causa de esta escasa contribución de la clorofila en la transparencia del agua hay que buscarla en la gran cantidad de material detrítico que hay en Sau, debido, tanto a los aportes de materia orgánica particulada alóctona, como a la resuspensión de sedimento del fondo y de la orilla que se produce en los periodos de sequía. Para el periodo de mayo de 2000 a diciembre de 2001 se ha realizado una descomposición de $k_{T}$ y $Z_{S D}$ mediante el método de regresión múltiple para conocer la contribución de los diferentes componentes disueltos y particulados. Las variables consideradas han sido concentración de clorofila, materia orgánica particulada detrítica, materia inorgánica y fitoplancton como partícula, además del efecto del agua. Los resultados muestran que el material particulado detrítico, que contribuye entre el $11 \%$ y $63.5 \%$ de $k_{T}$ y entre el $20.3 \%$ y $86 \%$ de $Z_{S D}$, es el factor más importante en la transparencia del agua. Estos resultados muestran que la radiación difusa o escalar es mucho más importante que la vectorial o direccional y que ,por tanto, el disco de Secchi es un buen descriptor del clima lumínico aunque no de la concentración de clorofila.

Palabras clave: profundidad de vision del disco de Secchi, coeficiente de extinción de la luz, transparencia del agua, clorofila-a, sólidos en suspensión, tripton, materia inorgánica

Limnetica 22(1-2): 195-210 (2003). DOI: 10.23818/limn.22.13

(c) Asociación Ibérica de Limnología, Madrid. Spain. ISSN: 0213-8409 


\section{INTRODUCTION}

The electromagnetic radiation of the visible spectrum (400-700 nm), which approximately corresponds to the photosynthetically active radiation (PAR), penetrates in water were it is absorbed and reflected, and the proportion of photons of different wavelength varies with depth. At each depth, changes produced in radiation generate certain light conditions that are denominated light climate. Although at present there are many electronic instruments designed for measuring light intensity at different depths, Secchi disk is the more widely used device.

The depth at which Secchi disk is no longer visible $\left(Z_{S D}\right)$ is a routinely way to measure water transparency, that has been broadly used in both marine and freshwater environments. Many limnologists have used $\mathrm{Z}_{\mathrm{SD}}$ as a descriptor of phytoplankton biomass, and from this relationship assess the trophic evolution of a lake. There is almost no lotic system in which $Z_{\mathrm{SD}}$ has not been used to describe the different stages of the increase of algal biomass at different temporal scales; for example, bloom development, seasonal changes (Bleiker \& Schanz, 1997), and annual cycle (Capblanq et al. 1994; Philips et al, 1997). In some cases, $Z_{\mathrm{SD}}$ has been used as a descriptor of the trophic evolution of a lake along time, as it is the case of Lake Washington (Edmondson, 1972), Lake Mendota (Lathrop et al, 1997) or Lake Tahoe (Jassby et al, 1999). Other authors, such as Shapiro et al, 1975; Carlson, 1977; Oglesby \& Schaffner, 1975 , considered that $Z_{\mathrm{SD}}$ is strongly influenced by chlorophyll- $a$ concentration and they use it as the basis to establish an index of trophic state. Even though this relationship was criticized by Edmondson (1980), Lorenzen (1980), and Megard et al (1980), it is widely used as a method to determine the trophic state of a lacustrine ecosystem.

An important part of these criticisms to the generalized use of $Z_{\mathrm{SD}}$ to estimate phytoplankton biomass is that other factors in addition to chlorophyll- $a$ can influence water transparency.
In fact, Secchi disk is also a very useful device to estimate the presence of suspended solids, being sediments transported by the lake or allochthonous or autochthonous detritic material (Lind, 1986; Morales et al, 1991; Lind et al, 1992). The same can be said about the use of $\mathrm{Z}_{\mathrm{SD}}$ in waters with high concentrations of humic substances or other compounds that colour the water. Finally, it must be taken into account that phytoplankton acts both as a pigment and as particulate material, and that chlorophyll content per cell is not constant (Edmonson, 1980).

In spite of these limitations, Secchi disk is considered a very useful instrument to measure water transparency and the incidence of light on biological activity (Preisendorfer, 1986). Currently, the use of $Z_{S D}$ is widely used as a measure of the photic layer, or zone in which light intensity is $1 \%$ (Schindler, 1971; Margalef, 1983; Kalff, 2002). With the development of electronic equipment for light measurement (radiometers, quantometers, photometers), measurements of water transparency and light extinction coefficient have become more objective. The first attempts in search of empirical relationships between $Z_{S D}$ and light extinction coefficient $\left(\mathrm{k}_{\mathrm{T}}\right)$, estimated using the LambertBeer equation, where performed in marine and lacustrine ecosystems. The pioneer study by Poole \& Atkins (1929) established for the marine environment the relation,

$$
\mathrm{Z}_{\mathrm{SD}} * \mathrm{k}_{\mathrm{T}}=\mathrm{K}
$$

where $\mathrm{K}=$ constant $=1.7$. For a long time, when no adequate electronic instruments were available, this equation (1) was used as a fast way to measure $\mathrm{k}_{\mathrm{T}}$ (Wetzel, 1983, Kalff, 2002). Calibration of this equation (1) from comparisons among measurements of $Z_{\mathrm{SD}}$ and $\mathrm{k}_{\mathrm{T}}$ has led to a wide range of estimated values for $\mathrm{K}$, that have been summarized by Koenings \& Edmundson (1991) and Kalff (2002). Currently, both $Z_{\mathrm{SD}}$ and $\mathrm{k}_{\mathrm{T}}$ are considered to be estimations, not completely equivalent, of water transparency that is affected by the water itself as well as by dissolved compounds and suspended 
materials (Kirk, 1994). The unequal content of different compounds that can reduce the transmission of light is one of the factors that affects the value of K. Results obtained from several Spanish reservoirs show that $\mathrm{K}$ ranges from 1.7 to 2.4 (Margalef et al., 1976; Rull et al., 1984) assuming that these variations are due to the different concentration of suspended solids.

Currently, a double system persists of measuring, when possible, light extinction with Secchi and with an underwater radiometer to relate both variables. In the Sau reservoir, these simultaneous measurements have been taken since 1995, and in this study we will analyse the temporal evolution of both variables as a function of chlorophyll- $a$ (chl- $a$ ) and suspended matter $\left(\mathrm{SS}_{\mathrm{T}}\right)$ concentrations at different moments in the annual cycle. For the period 2000-2001, we partitioned $\mathrm{SS}_{\mathrm{T}}$ as the sum of detritic particulate organic matter (pom-detri), particulate inorganic matter (p-inor), and phytoplankton considered as particulate material (p-phyto). This information was used to establish their influence on light transmission in water estimated from $Z_{S D}$ and $k_{T}$ values.

\section{MATERIALS AND METHODS}

All data used in this study were collected in Sau reservoir's station 1, located $1000 \mathrm{~m}$ from the dam on the deepest point along the transversal axis. Samples were taken monthly at $0,2,3$ and $10 \mathrm{~m}$ depth. Values of the different variables were expressed as mean concentrations for this water layer, whose depth coincides with the depth of the epilimnion during the summer months. At each sampling occasion, transparency was estimated with a Secchi disk $30 \mathrm{~cm}$ in diameter. From 1997, vertical profiles of photosynthetically active radiation (PAR) were obtained with a radiometer Li-Cor 185B with a sensor that can measure diffuse radiation (spherical sensor LI-193SA, Li-Cor Inc., Lincoln, Nebraska). Measurements of incoming radiation, $\mathrm{I}_{\mathrm{z}}$, were estimated every $0.5 \mathrm{~m}$ from the water surface to $9 \mathrm{~m}$ in depth, and were adjusted by lineal regression to the Lambert-Beer equation to estimate an integrated extinction coefficient for PAR:

$$
k_{T}=\left(\ln \frac{I_{z}}{I_{o}}\right) \frac{1}{z}
$$

where $\mathrm{I}_{0}$ and $\mathrm{I}_{\mathrm{z}}$ are light intensities at 0 and $\mathrm{z}$ meters depth respectively, and $\mathrm{k}_{\mathrm{T}}\left(\mathrm{m}^{-1}\right)$ is the light extinction coefficient.

Chlorophyll- $a$ concentration was estimated by the trichromatic method of Jeffrey \& Humphrey (1975). Samples were previously filtered through Whatman GF/F fiber filters from a known water volume, and chlorophyll was extracted from the retained cells with a $90 \%$ acetone solution.

Suspended solids concentration $\left(\mathrm{SS}_{\mathrm{T}}\right)$ was obtained as the difference between the weight of a GF/F filter before and after the filtration of a known water volume. Before being weighed, filters were dried at $105{ }^{\circ} \mathrm{C}$ during $24 \mathrm{hrs}$. Since 2000 , dried and weighed filters are incinerated in a muffle furnace at $550^{\circ} \mathrm{C}$ to determine ash weight and, consequently, suspended inorganic solids $\left(\mathrm{SS}_{\mathrm{p} \text {-inor }}\right)$ and volatilised solids $\left(\mathrm{SS}_{\mathrm{pom}}\right)$. All analyses were made according to the methods described in APHA (1992).

$\mathrm{SS}_{\mathrm{T}}$ concentration was divided in three fractions:

1) $\mathrm{SS}_{\mathrm{p} \text {-phyto }}$ that corresponds to the organic dry weight fraction of phytoplankton, assuming the relation $\mathrm{SS}_{\mathrm{p} \text {-phyto }(\mathrm{mg} / \mathrm{L})}=100 *$ [Chlorophyll-a] (mg/L) (Reynolds, 1984; Philips et al, 1995, Effler et al, 2002);

2) $\mathrm{SS}_{\mathrm{p} \text {-inor }}$ which is the inorganic fraction and it is assumed to be mostly composed by suspended sediments originated from the shores or transported by the river; and

3) $\mathrm{SS}_{\text {p-inor }}$ or detritic organic material, which can be allochthonous or autochthonous in origin, and can be estimated from the relation $\mathrm{SS}_{\text {pom-detri }}=\mathrm{SS}_{\mathrm{T}}-\mathrm{SS}_{\mathrm{p} \text {-phyto }}-\mathrm{SS}_{\mathrm{p} \text {-inor }}$.

Water colour has not been considered because the presence of humic acids or coloured compounds is not significant in Sau reservoir due to basin characteristics. 


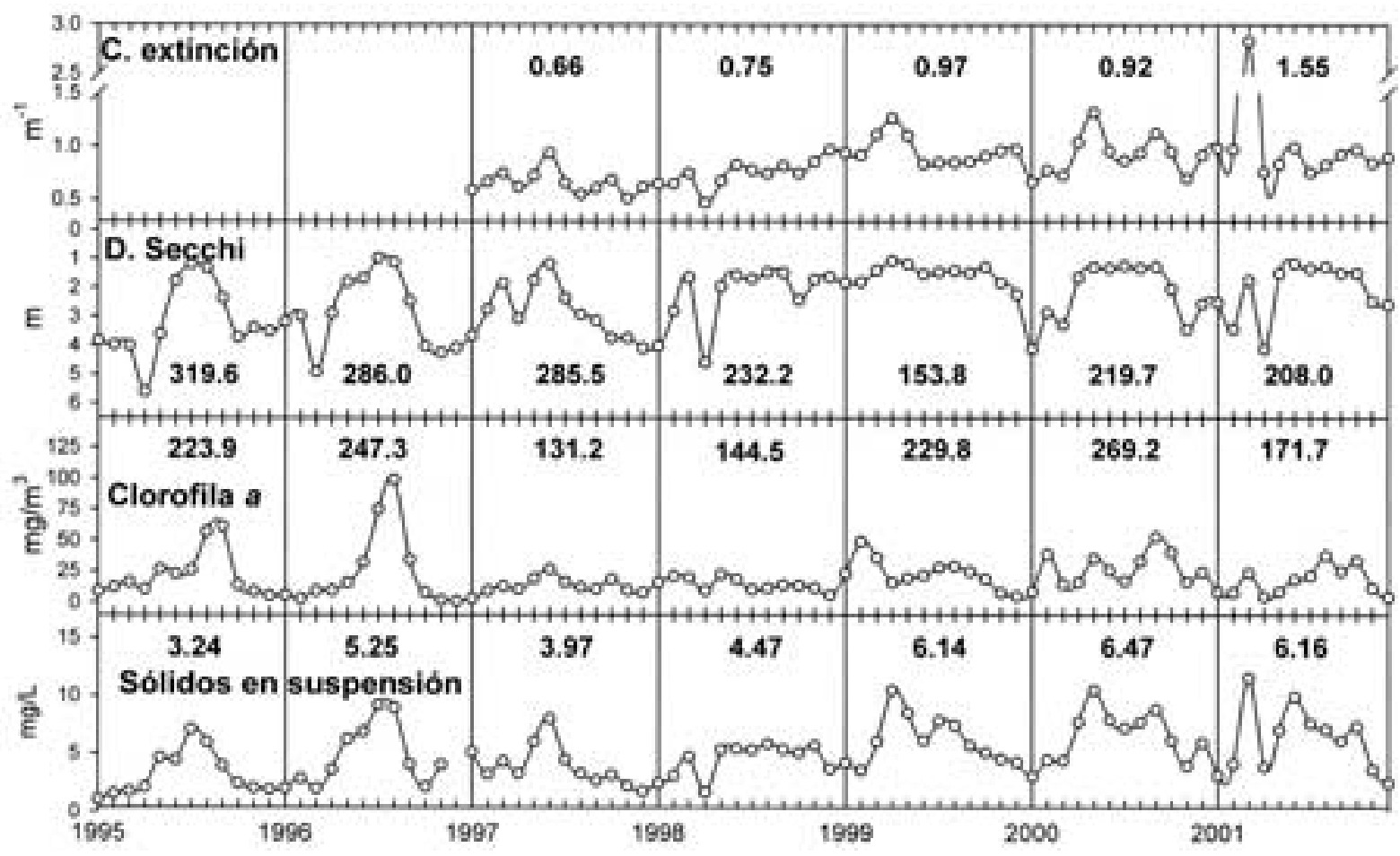

Figure 1. Monthly variation of the light attenuation coefficient, Secchi depth, chlorophyll- $a$, and suspended matter concentrations. Annual averages are also indicated for each year. Variabilidad mensual del coeficiente de extinción de la luz, de la profundidad de visión del disco de Secchi y de las concentraciones de clorofila a y de sólidos en suspensión. Para cada año se indica también los valores medios anuales.

\section{RESULTS}

Figure 1 shows the values of the different variables measured or estimated from 1995 to 2001. Since 1997, when $\mathrm{k}_{\mathrm{T}}$ values became available, they ranged from $0.34 \mathrm{~m}^{-1}$ to $3.75 \mathrm{~m}^{-1}$, but the upper range corresponds to a Rhodomonas minuta bloom in March 2001. Except for this value, $\mathrm{k}_{\mathrm{T}}$ never exceeded $1.44 \mathrm{~m}^{-1}$, with a mean of $0.84 \pm 0.09 \mathrm{~m}^{-1}$ for the whole period studied. No noticeable pattern of temporal variation of phytoplankton was observed, except for a slight increase of chlorophyll- $a$ concentrations during February due to the algal development in spring, followed by lower values in March or April depending on the year considered, associated with the clear phase. Since rainfall periods were irregular and occasionally heavy, changes in $\mathrm{k}_{\mathrm{T}}$ associated to chlorophyll- $a$ fluctuations were often masked by the input of suspended solids and detritic material.
Secchi disk depth $\left(Z_{\mathrm{SD}}\right)$ ranged from $0.4 \mathrm{~m}$ to $6.35 \mathrm{~m}$ with a mean value of $2.57 \pm 0.27 \mathrm{~m}$. Unlike $\mathrm{k}_{\mathrm{T}}, \mathrm{Z}_{\mathrm{SD}}$ showed a more regular annual pattern, especially due to the increase in transparency in spring related to the clear phase, in which $Z_{S D}$ usually reaches its' annual peak, very different from the rest of the year (Fig. 1). In most years, except for 1998, a second peak of transparency was observed in winter coinciding with the lower abundance of phytoplankton in this period.

Until 1990, the Sau reservoir was hypertrophic, but the construction of tertiary sewage treatment plants in its' basin, allowed for a recovery towards eutrophy in recent years. In the period 1995-97 chlorophyll- $a$ concentration ranged from $0.23 \mathrm{mg} / \mathrm{L}$ to $107.36 \mathrm{mg} / \mathrm{L}$ with a mean of $19.84 \pm 4.18 \mathrm{mg} / \mathrm{L}$. This wide range of variation is due to the fact that the data presented here corresponds to two management strategies in the Sau reservoir that have influenced 
the annual fluctuations of chlorophyll- $a$ concentrations. Until 1996, the outlet of the reservoir was the deepest of the three possible ones, and thermal stability of the metalimnion was relatively low at the end of the summer. As a consequence of this management of the reservoir, the onset of the mixing period started at the end of the summer season. The mixture of the epilimnion with the metalimnion produced an upward flow of nutrients into the upper water layers; consequently, phytoplankton attained a high development producing the maximum annual peak of chlorophyll- $a$ concentration (Fig. 1). From 1997, the outlet of the reservoir was changed to the closest one to the water surface and thermal stability at the end of summer substantially increased in relation to the former years; therefore, the onset of the mixing period was delayed and the late summer peak of chlorophyll- $a$ disappeared, considerably changing the seasonal dynamics of phytoplankton in relation to previous years. Chlorophyll- $a$ concentration is much more uniform along the year with two or three peaks that are much lower than those observed in the years previous to 1997. These peaks occur in spring (following the clear phase), and in summer, and in some years (like 1998) the last two peaks can overlap forming a sole maximum much more persistent in time.

As it was pointed out above, suspended solids concentration not only represent phytoplankton as particulate material, but detritic material and suspended sediments as well; therefore, its temporal evolution is complex. As figure 1 shows, peaks of chlorophyll- $a$ and suspended solids concentrations showed some coincidence in time, although there were other peaks that cannot be related to phytoplankton and that can be attributed to inputs from the river o from the shores. Suspended solids concentration ranged from $0.81 \mathrm{mg} / \mathrm{L}$ to $15.21 \mathrm{mg} / \mathrm{L}$ with a mean value of $5.08 \pm 0.66 \mathrm{mg} / \mathrm{L}$.

\section{Relations between $\mathrm{Z}_{\mathrm{SD}}$ and $\mathrm{k}_{\mathrm{T}}$}

$\mathrm{Z}_{\mathrm{SD}} \mathrm{y} \mathrm{k}_{\mathrm{T}}$ correlated significantly for the whole studied period as well as for each year considered individually (Table 1). In this table, data from 2001 are exceptional due to the presence in February of a Rhodomonas bloom that greatly reduced water transparency, which reached the lowest value for the whole period under consideration $\left(\mathrm{k}_{\mathrm{T}}=3.75\right.$ y $\left.\mathrm{Z}_{\mathrm{SD}}=0.4 \mathrm{~m}\right)$. Since Poole \& Atkins's work (1929), there were many comparisons between $\mathrm{Z}_{\mathrm{SD}}$ and $\mathrm{k}_{\mathrm{T}}$ considering that both variables are estimations of water transparency and that they are related by equation (1). In figure 2 it can be seen that both variables are significantly correlated being $\mathrm{k}_{\mathrm{T}}=1.36 \mathrm{Z}_{\mathrm{SD}}{ }^{-0806}\left(\mathrm{r}^{2}=0.7\right.$; $\mathrm{p}<0.001)$. This equation is not considerably different from the relation $\mathrm{k}_{\mathrm{T}} * \mathrm{Z}_{\mathrm{SD}}=1.7$ established by Poole \& Atkins (1929). Nevertheless, when this relation is calculated for each year (Table 1), the product $\mathrm{k}_{\mathrm{T}} * \mathrm{Z}_{\mathrm{SD}}$ showed a considerable interannual variability, ranging from 1.49 in 1999 to 1.94 in 2000 . The product calculated for the whole period 1997-2001 is 1.78 .

\section{Relations among $\mathrm{Z}_{\mathrm{SD}}, \mathrm{k}_{\mathrm{T}}$ and chlorophyll-a concentration}

From the data gathered from 1995 to 2001, it can be assumed that water transparency in Sau reservoir is not a consequence of chlorophyll- $a$ concentration. Indeed, as it can be seen in figure 3 , there is no direct relation between chlorophyll content and $\mathrm{Z}_{\mathrm{SD}}$ or $\mathrm{k}_{\mathrm{T}}$ (Fig. 3). Nevertheless, when these relations are calculated for each year (Tables 2 and 3), a different behaviour can be seen among these variables. $Z_{\mathrm{SD}}$ was a good descriptor of chlorophyll- $a$ concentration from 1995 to 1997 and in 2001 (Table 2). On the other hand, correlation between chlorophyll- $a$ and $\mathrm{k}_{\mathrm{T}}$ was significant only for 1997 (Table 3), although we have no data of $\mathrm{k}_{\mathrm{T}}$ for 1995 and 1996.

\section{Relations among $\mathbf{Z}_{\mathrm{SD}}, \mathrm{k}_{\mathrm{T}}$ and suspended solids concentration}

Unlike chlorophyll- $a$ concentration, suspended solids $\left(\mathrm{SS}_{\mathrm{T}}\right)$ seem to contribute significantly to water transparency taking into account the relation found between $Z_{\mathrm{SD}}$ and $\mathrm{k}_{\mathrm{T}}$ (Fig. 4). In this way, for the period $1995-2001 \mathrm{SS}_{\mathrm{T}}$ was signifi- 
Table 1. Equations relating the light attenuation coefficient, $\mathrm{k}_{\mathrm{T}}$, and Secchi depth, $\mathrm{Z}_{\mathrm{SD}}$, and the corresponding determination coefficient for each year and for the whole studied period. The last column shows the value of the product $\mathrm{k}_{\mathrm{T}} * \mathrm{Z}_{\mathrm{SD}}$. Ecuaciones que relacionan el coeficiente de extinción de la luz, $k_{T}$, con la profundidad de visión del disco de Secchi, $Z_{S D}$, y su coeficiente de determinación para cada año estudiado y para todo el periodo considerado. En la última columna se indica el valor del producto de las variables $k_{T} * Z_{S D}$.

\begin{tabular}{llcc}
\hline Year & Equation & $\mathbf{r}^{2}$ & $\mathbf{k}_{\mathbf{T}} * \mathbf{Z}_{\mathbf{S D}}=\mathbf{c t}$ \\
\hline 1997 & $\mathrm{k}_{\mathrm{T}}=0.97 \mathrm{Z}_{\mathrm{SD}}{ }^{-0.39}$ & 0.67 & 1.88 \\
1998 & $\mathrm{k}_{\mathrm{T}}=0.93 \mathrm{Z}_{\mathrm{SD}}{ }^{-0.39}$ & 0.69 & 1.63 \\
1999 & $\mathrm{k}_{\mathrm{T}}=1.22 \mathrm{Z}_{\mathrm{SD}^{-0.52}}$ & 0.52 & 1.49 \\
2000 & $\mathrm{k}_{\mathrm{T}}=1.17 \mathrm{Z}_{\mathrm{SD}^{-0.42}}$ & 0.70 & 1.98 \\
2001 & $\mathrm{k}_{\mathrm{T}}=134 \mathrm{Z}_{\mathrm{SD}^{-0.98}}$ & 0.88 & 1.78 \\
$1997-01$ & $\mathrm{k}_{\mathrm{T}}=1.36 \mathrm{Z}_{\mathrm{SD}^{-0.806}}$ & 0.70 & 1.78 \\
\hline
\end{tabular}

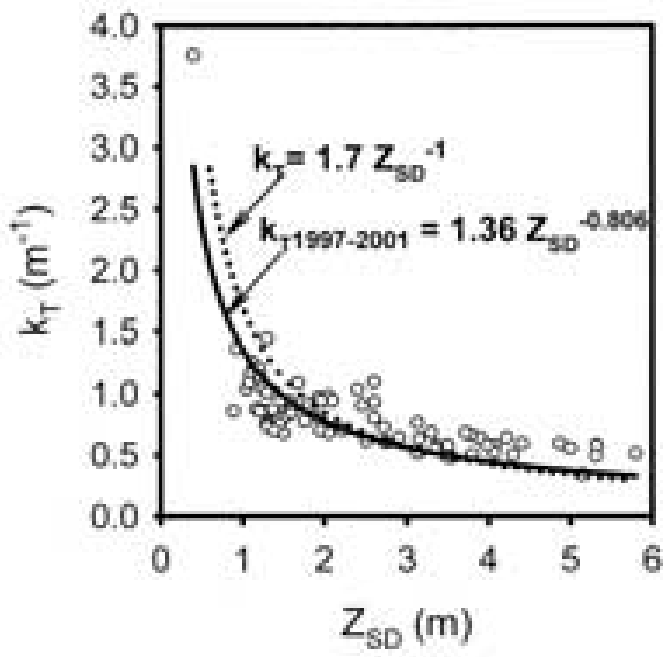

Figure 2. Relationship between light attenuation coefficient and Secchi depth. The solid line indicates the resulting exponential equation, while the dotted line represents the relation proposed by Poole \& Atkins (1929). It can be seen that for almost all the measured data points with values of $\mathrm{k}_{\mathrm{T}}<1.5$, both lines show only minor differences, and can be indistinctly used. Relación entre el coeficiente de extinción de la luz y la profundidad de visión del disco de Secchi. En línea continua se indica la ecuación potencial resultante, mientras que en linea de puntos se indica la relación establecida por Poole \& Atkins (1929). Se puede observar que para casi todos los puntos medidos con valores $k_{T}<1.5$ ambas curvas presentan diferencias muy pequeñas por los que se pueden usar indistintamente.

cantly correlated with $\mathrm{Z}_{\mathrm{SD}}\left(\mathrm{r}^{2}=0.79, \mathrm{p}<0.001\right)$ and with $\mathrm{k}_{\mathrm{T}}\left(\mathrm{r}^{2}=0.5, \mathrm{p}<0.001\right)$. Consequently, it can be assumed that $Z_{\mathrm{SD}}$ is more adequate to estimate $\mathrm{SS}_{\mathrm{T}}$ than $\mathrm{k}_{\mathrm{T}}$. Considering the years individually,
$\mathrm{SS}_{\mathrm{T}}$ and $\mathrm{Z}_{\mathrm{SD}}$ are significantly correlated for all the years (Table 4). The relation between $\mathrm{SS}_{\mathrm{T}} \mathrm{y} \mathrm{k}_{\mathrm{T}}$ shows the same pattern except for 2001 (Table 5).

\section{The components of $k_{T}$ for the period 2000-2001}

Although it cannot be considered completely exact, $\mathrm{k}_{\mathrm{T}}$ can be assumed as the sum of the light extinction coefficients associated to the different dissolved compounds or suspended particles that can be found in the photic zone (Kirk, 1994). In the Sau reservoir, we assumed that there is not a significant concentration of compounds that can give colour to water; consequently,

$$
\begin{aligned}
\mathrm{k}_{\mathrm{T}}= & \mathrm{k}_{\mathrm{w}}+\mathrm{k}_{\mathrm{chl}}+\mathrm{k}_{\text {pom-detri }}+ \\
& +\mathrm{k}_{\mathrm{p} \text {-inor }}+\mathrm{k}_{\text {p-phyto }}
\end{aligned}
$$

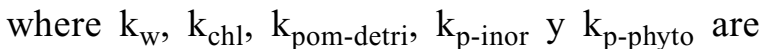
respectively the partial extinction coefficients of water, chlorophyll- $a$, detritic organic material, inorganic matter, and phytoplankton considered as particulate material (Reynolds, 1984; Kirk, 1994). The estimation of $\mathrm{k}_{\mathrm{T}}$ from equation (3) has been made according to the lineal regression method described by Reynolds (1984) using data obtained in the Sau reservoir from May 2000 until December 2001. First, as

Table 2. Relationships between chlorophyll-a concentration and Secchi depth for each year and for the whole studied period. The coefficient of determination is also indicated when $\mathrm{p} \leq 0.05$; n.s. means not significant. Ecuaciones que relacionan la concentración de clorofila a con la profundidad de visión del disco de Secchi para cada año estudiado y para todo el periodo considerado, se indica, además, el coeficiente de determinación cuando es significativo para un valor $p \leq 0.05$; n.s. es no significativo.

\begin{tabular}{lll}
\hline Year & \multicolumn{1}{c}{ Equation } & $\mathbf{r}^{2}$ \\
\hline 1995 & {$[$ chl- $a]=51.45 \mathrm{Z}_{\mathrm{SD}}{ }^{-1.03}$} & 0.63 \\
1996 & {$[$ chl- $a]=88.51 \mathrm{Z}_{\mathrm{SD}^{-2.23}}$} & 0.70 \\
1997 & {$[$ chl- $a]=29.74 \mathrm{Z}_{\mathrm{SD}^{-0.95}}$} & 0.42 \\
1998 & {$[$ chl- $a]=13.09 \mathrm{Z}_{\mathrm{SD}}{ }^{0.06}$} & n.s. \\
1999 & {$[$ chl- $a]=31.98 \mathrm{Z}_{\mathrm{SD}^{-1.12}}$} & n.s. \\
2000 & {$[$ chl- $a]=37.78 \mathrm{Z}_{\mathrm{SD}^{-0.66}}$} & n.s. \\
2001 & {$[$ chl- $a]=34.84 \mathrm{Z}_{\mathrm{SD}^{-1.45}}$} & 0.63 \\
$1997-01$ & {$[$ chl- $a]=42.80 \mathrm{Z}_{\mathrm{SD}^{-1.04}}$} & n.s.
\end{tabular}



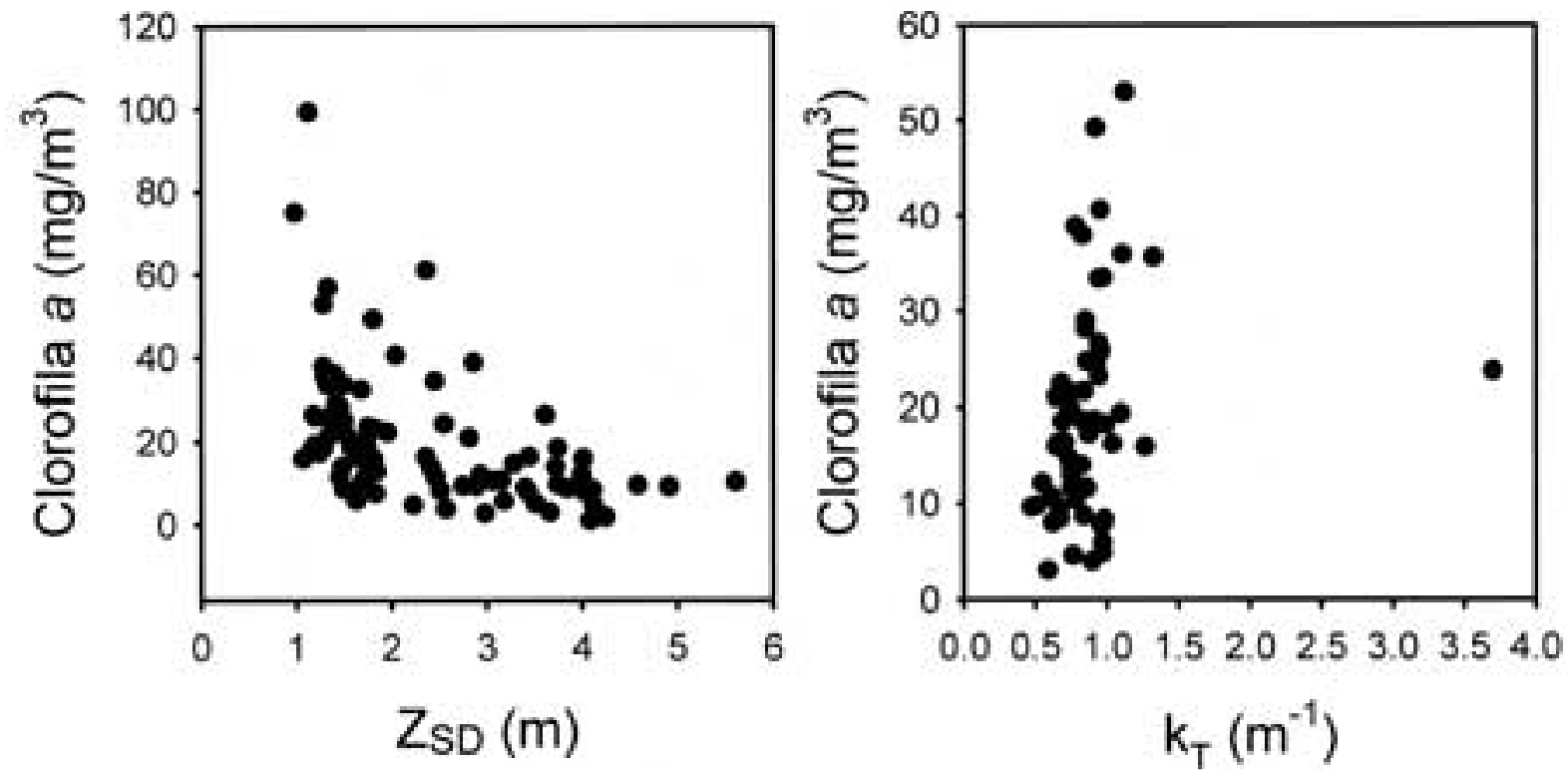

Figure 3. Relationships between chlorophyll-a concentration and Secchi depth (left) and light attenuation coefficient (right). In both cases the relations are not significant when an exponential regression is used for $\mathrm{Z}_{\mathrm{SD}}$ or a lineal one is used for $\mathrm{k}_{\mathrm{T}}$. Relaciones entre la concentración de clorofila a y la profundidad de visión del disco de Secchi (izquierda) y coeficiente de extinción de la luz (derecha). En ambos casos la relación es no significativa cuando se aplica una regresión potencial con $Z_{S D}$ o lineal con $k_{T}$.
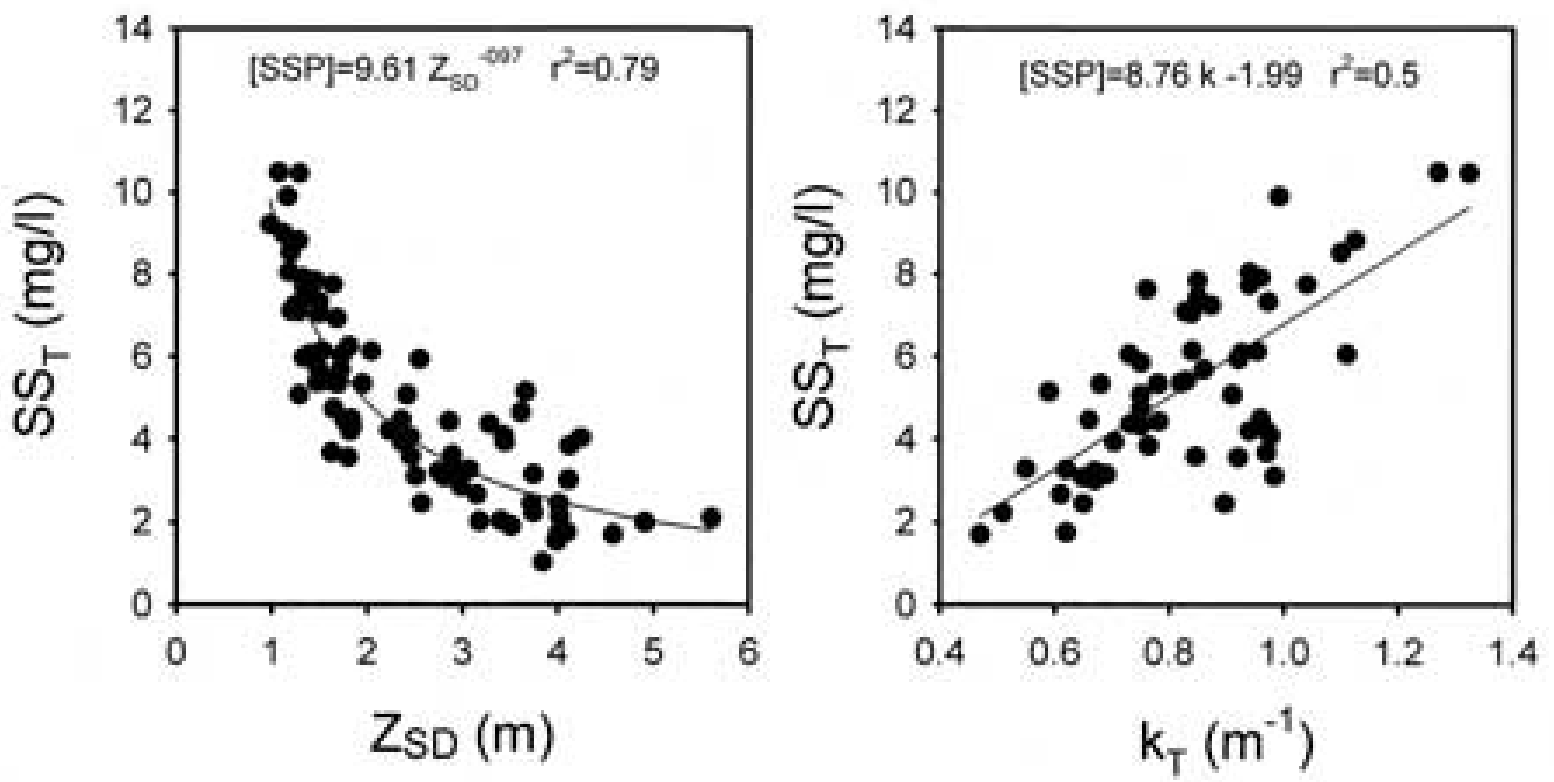

Figure 4. Relationships between suspended solids concentration and Secchi depth (left) and light attenuation coefficient (right). In both cases the relationship is significant $(\mathrm{p} \leq 0.05)$ when an exponential regression is used for $\mathrm{Z}_{\mathrm{SD}}$ or a lineal one is used for $\mathrm{k}_{\mathrm{T}}$. Relaciones entre la concentración de sólidos en suspensión y la profundidad de visión del disco de Secchi (izquierda) y coeficiente de extinción de la luz (derecha). En ambos casos la relación es significativa $(p \leq 0.05)$ cuando se aplica una regresión potencial con $Z_{S D}$ o lineal con $k_{T}$ 
Table 3. Equations relating chlorophyll-a concentration and light attenuation coefficient for each year and for the whole studied period. The coefficient of determination is also indicated when $\mathrm{p} \leq 0.05$ or less; not significant. Ecuaciones que relacionan la concentración de clorofila a con el coeficiente de extinción de la luz para cada año estudiado y para todo el periodo considerado, se indica, además, el coeficiente de determinación cuando es significativo para un valor $p \leq 0.05$; n.s. No significativo.

\begin{tabular}{lll}
\hline Year & \multicolumn{1}{c}{ Equation } & $\mathbf{r}^{2}$ \\
\hline 1997 & {$[\mathrm{chl}-a]=43.96 \mathrm{k}_{\mathrm{T}}-15.97$} & 0.63 \\
1998 & {$[\mathrm{chl}-a]=23.13 \mathrm{k}_{\mathrm{T}}-11.50$} & n.s. \\
1999 & {$[\mathrm{chl}-a]=38.40 \mathrm{k}_{\mathrm{T}}-15.7$} & n.s. \\
2000 & {$[\mathrm{chl}-a]=41.46 \mathrm{k}_{\mathrm{T}}-11.04$} & n.s. \\
2001 & {$[\mathrm{chl}-a]=3.7 \mathrm{k}_{\mathrm{T}}-13.12$} & n.s. \\
$1997-01$ & {$[\mathrm{chl}-a]=10.04 \mathrm{k}_{\mathrm{T}}-10.26$} & n.s. \\
\hline
\end{tabular}

$\mathrm{SS}_{\mathrm{T}}$ seems to be the more important component of equation (3), we calculated the lineal regression between $\mathrm{k}_{\mathrm{T}}$ and $\mathrm{SS}_{\mathrm{T}}$ (Fig. 5), obtaining the following relation,

$$
\begin{aligned}
& \mathrm{k}_{\mathrm{T}}=6.45 \cdot 10^{-5}\left[\mathrm{SS}_{\mathrm{T}}\right]_{\left(\mathrm{mg} / \mathrm{m}^{3}\right)}+0.4806 \\
& \mathrm{r}^{2}=0.64, \mathrm{n}=18, \mathrm{p}<0.001
\end{aligned}
$$

where 0.4807 represents the sum of $\mathrm{k}_{\mathrm{w}}$ and $\mathrm{k}_{\mathrm{chl}}$ in equation (3). Reynolds (1979) considered that $\mathrm{k}_{\mathrm{W}}$ ranged from 0.08 to $0.11 \mathrm{~m}^{-1}$. If we assume that $\mathrm{k}_{\mathrm{w}}=0.09 \mathrm{~m}^{-1}$, the value of $\mathrm{k}_{\text {clor }}$ will be $0.3906 \mathrm{~m}^{-1}$ (Fig. 5A). The mean contribution of

Table 4. Equations relating the concentration of total suspended material with Secchi depth for each year and for the whole studied period. The coefficient of determination is also indicated when $\mathrm{p} \leq 0.05$. Ecuaciones que relacionan la concentración de sólidos en suspensión con la profundidad de visión del disco de Secchi para cada año estudiado y para todo el periodo considerado, se indica, además, el coeficiente de determinación cuando es significativo para un valor $p<0.05$.

\begin{tabular}{lll}
\hline Year & \multicolumn{1}{c}{ Equation } & \multicolumn{1}{c}{$\mathbf{r}^{\mathbf{2}}$} \\
\hline 1995 & $\mathrm{SS}_{\mathrm{T}}=8.19 \mathrm{Z}_{\mathrm{SD}^{-0.97}}$ & 0.8 \\
1996 & $\mathrm{SS}_{\mathrm{T}}=9.66 \mathrm{Z}_{\mathrm{SD}^{-0.92}}$ & 0.91 \\
1997 & $\mathrm{SS}_{\mathrm{T}}=9.14 \mathrm{Z}_{\mathrm{SD}^{-0.9}}$ & 0.77 \\
1998 & $\mathrm{SS}_{\mathrm{T}}=7.54 \mathrm{Z}_{\mathrm{SD}^{0.76}}$ & 0.72 \\
1999 & $\mathrm{SS}_{\mathrm{T}}=10.84 \mathrm{Z}_{\mathrm{SD}^{-1.47}}$ & 0.74 \\
2000 & $\mathrm{SS}_{\mathrm{T}}=10.31 \mathrm{Z}_{\mathrm{SD}^{-0.74}}$ & 0.85 \\
2001 & $\mathrm{SS}_{\mathrm{T}}=10.55 \mathrm{Z}_{\mathrm{SD}^{-0.92}}$ & 0.55 \\
$1997-01$ & $\mathrm{SS}_{\mathrm{T}}=9.61 \mathrm{Z}_{\mathrm{SD}^{-0.97}}$ & 0.79 \\
\hline
\end{tabular}
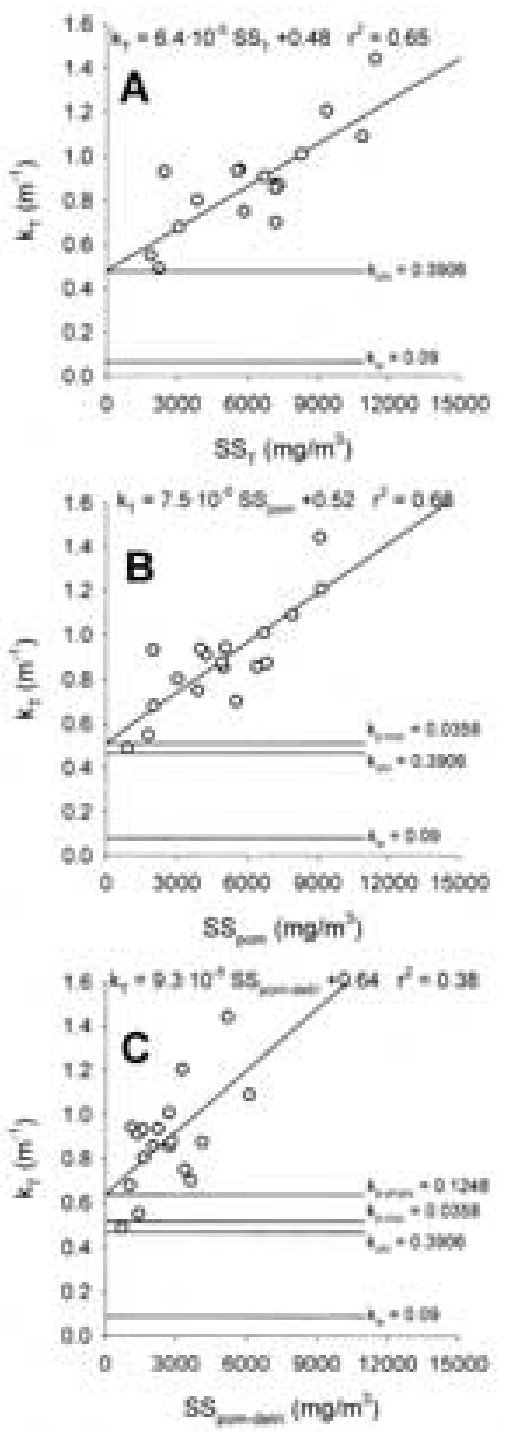

Figure 5. Partitioning of $\mathrm{k}_{\mathrm{T}}$ using the multiple lineal regression method. In a first step (A) the effect of chlorophyll- $a$ concentration $\left(\mathrm{k}_{\mathrm{chl}}\right)$ and of water $\left(\mathrm{k}_{\mathrm{w}}\right)$ are calculated, while in the intermediate step (B) the effect of the inorganic suspended material $\left(\mathrm{k}_{\mathrm{p}}\right.$ inor) is included. Finally, C, the effect of the phytoplankton considered as organic particulate matter $\left(\mathrm{k}_{\mathrm{p} \text {-phyto }}\right)$ is also considered. In the last step, the resulting regression line relates the organic detritic material concentration $\left(\mathrm{k}_{\text {pom-detri }}\right)$ to the light attenuation coefficient $\mathrm{k}_{\mathrm{T}}$. Descomposición de $k_{T}$ mediante el método de regresión lineal multiple. En un primer paso, A, se obtiene el efecto de la concentración de clorofila a, $k_{c h}$, y del agua, $k_{w}$, mientras en la fase intermedia, $B$, se añade el efecto del material inorgánico, $k_{p \text {-inor }} y$, finalmente, $C$, se incluye el efecto del fitoplancton, $k_{p-}$ phyto, considerado como partícula de material orgánico. En este último caso la recta de regresión resultante establece la relación entre la concentración de material detrítico orgánico y el coeficiente de extinción de la luz, $k_{\text {pom-detri }}$. 
Table 5. Equations relating the concentration of total suspended material with the light attenuation coefficient for each year and for the whole studied period. The coefficient of determination is also indicated when significant for $\mathrm{p} \leq 0.05$. Ecuaciones que relacionan la concentración de sólidos en suspensión con el coeficiente de extinción de la luz para cada año estudiado y para todo el periodo considerado, se indica, además, el coeficiente de determinación cuando es significativo para un valor $p \leq 0.05$.

\begin{tabular}{llc}
\hline Year & \multicolumn{1}{c}{ Equation } & $\mathbf{r}^{2}$ \\
\hline 1997 & $\mathrm{SS}_{\mathrm{T}}=12.52 \mathrm{k}_{\mathrm{T}}-4.32$ & 0.63 \\
1998 & $\mathrm{SS}_{\mathrm{T}}=6.71 \mathrm{k}_{\mathrm{T}}-0.53$ & 0.37 \\
1999 & $\mathrm{SS}_{\mathrm{T}}=8.17 \mathrm{k}_{\mathrm{T}}-17.5$ & 0.37 \\
2000 & $\mathrm{SS}_{\mathrm{T}}=9.62 \mathrm{k}_{\mathrm{T}}-2.15$ & 0.87 \\
2001 & $\mathrm{SS}_{\mathrm{T}}=4.26 \mathrm{k}_{\mathrm{T}}-2.03$ & n.s. \\
$1997-01$ & $\mathrm{SS}_{\mathrm{T}}=8.76 \mathrm{k}_{\mathrm{T}}-1.99$ & 0.49 \\
\hline
\end{tabular}

a unit of chlorophyll- $a$ to $\mathrm{k}_{\text {clor }}$ will be $\mathrm{k}_{\text {clor }}$ divided by the mean chlorophyll- $a$ concentration for the period $\left(23.09 \mathrm{mg} / \mathrm{m}^{3}\right)$; therefore,

$$
\mathrm{k}_{\mathrm{chl}}=0.0169_{\left(\mathrm{m}^{2} / \mathrm{mg}\right)}[\mathrm{chl} a]_{\left(\mathrm{mg} / \mathrm{m}^{3}\right)}
$$

The following step is to calculate the lineal regression between organic suspended solids concentration $\left(\mathrm{SS}_{\text {pom }}\right)$ and $\mathrm{k}_{\mathrm{T}}$ considering that $\mathrm{SS}_{\mathrm{pom}}=\mathrm{SS}_{\mathrm{T}}-\mathrm{SS}_{\mathrm{p} \text {-inor }}$, that is the concentration of suspended solids in organic form. The new regression line is:

$$
\begin{gathered}
\mathrm{k}_{\mathrm{T}}=7.48 \cdot 10^{-5}\left[\mathrm{SS}_{\mathrm{pom}}\right]_{\left(\mathrm{mg} / \mathrm{m}^{3}\right)}+0.5164 \\
\mathrm{r}^{2}=0.68, \mathrm{n}=18, \mathrm{p}<0.001
\end{gathered}
$$

but now, the intersection is the value for $\mathrm{k}_{\mathrm{w}}+$ $\mathrm{k}_{\text {clor }}+\mathrm{k}_{\mathrm{p} \text {-inor }}$. From equation (4) we know the value of $\mathrm{k}_{\mathrm{w}}+\mathrm{k}_{\text {clor }}$; consequently, $\mathrm{k}_{\mathrm{p} \text {-inor }}=$

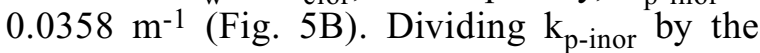
mean suspended solids concentration of the period $\left(1380 \mathrm{mg} / \mathrm{m}^{3}\right)$ we obtain $\mathrm{k}_{\mathrm{p} \text {-inor }}=$ $2.59 \cdot 10^{-5}\left(\mathrm{~m}^{2} / \mathrm{mg}\right)\left[\mathrm{SS}_{\mathrm{p} \text {-inor }}\right]_{\left(\mathrm{mg} / \mathrm{m}^{3}\right)}$, which is an estimation of the contribution of $\mathrm{SS}_{\mathrm{p} \text {-inor }}$ to $\mathrm{k}_{\mathrm{T}}$. This procedure can be repeated using the organic detritic material $\left(\mathrm{SS}_{\text {pom-detri }}=\mathrm{SS}_{\mathrm{T}}-\mathrm{SS}_{\mathrm{p} \text {-inor }}\right.$ $\left.-\mathrm{SS}_{\mathrm{p} \text {-phyto }}\right)$ as independent variable in the lineal regression, and so we obtain,

$$
\begin{gathered}
\mathrm{k}_{\mathrm{T}}=9.32 \cdot 10^{-5}\left[\mathrm{SS}_{\mathrm{pom}-\text { detri }}\right]_{(\mathrm{mg} / \mathrm{L})}+0.6412 \\
\mathrm{r}^{2}=0.38, \mathrm{n}=18, \mathrm{p}<0.01
\end{gathered}
$$

in which the difference between the intersects of equations (6) y (5) is $\mathrm{k}_{\mathrm{p} \text {-phyto }}$ (Fig. 5C). If we divide this value $\left(0.1248 \mathrm{~m}^{-1}\right)$ by the mean concentration of phytoplanktonic seston $\left(2310 \mathrm{mg} / \mathrm{m}^{3}\right)$, we obtained $5.4 \cdot 10^{-5}\left(\mathrm{~m}^{2} / \mathrm{mg}\right) \quad\left[\mathrm{SS}_{\mathrm{p} \text {-phyto }}\right]_{(\mathrm{mg} / \mathrm{L})}$. Now, we can replace the terms of equation (6) rewriting it as follows:

$$
\begin{gathered}
\mathrm{k}_{\mathrm{T}}=9.32 \cdot 10^{-5}\left[\mathrm{SS}_{\text {pom-detri }}\right]_{\left(\mathrm{mg} / \mathrm{m}^{3}\right)}+ \\
+1.69 \cdot 10^{-2}[\mathrm{chl} a]_{\left(\mathrm{mg} / \mathrm{m}^{3}\right)}+ \\
+2.59 \cdot 10^{-5}\left[\mathrm{SS}_{\mathrm{p}-\mathrm{inor}}\right]_{\left(\mathrm{mg} / \mathrm{m}^{3}\right)}+ \\
+5.4 \cdot 10^{-5}\left[\mathrm{SS}_{\mathrm{p}-\text { phyto }}\right]_{\left(\mathrm{mg} / \mathrm{m}^{3}\right)}+0.09
\end{gathered}
$$

where $k_{T}$ is the sum of all the partial light extinction coefficients considered in equation (3). In actuality, equation (7) only allows for an estimation of $\mathrm{K}_{\mathrm{T}}$ (that we will denominate $\mathrm{k}_{\text {Tcalc }}$ ) from the different variables that defined it. Consequently, for each sampling occasion we calculated a value for $\mathrm{k}_{\text {Tcalc }}$ that is an estimation of the measured $\mathrm{k}_{\mathrm{T}}$. Table 6 and figure 9 show the values of $\mathrm{k}_{\mathrm{w}}, \mathrm{k}_{\mathrm{clor}}, \mathrm{k}_{\text {pom-detri }}, \mathrm{k}_{\mathrm{p} \text {-inor }}$, $\mathrm{k}_{\mathrm{p} \text {-phyto }}$, and $\mathrm{k}_{\text {Tcalc }}$ estimated according to (7) for the 18 samplings performed between May 2000 and December 2001. As it is shown in Fig. 6 , the relationship between observed and measured light extinction coefficients can be expressed as follows:

$$
\begin{gathered}
\mathrm{k}_{\mathrm{T}}=0.42 \mathrm{k}_{\mathrm{Tcalc}}+0.51 \\
\mathrm{r}^{2}=0.65 \quad \mathrm{n}=18, \quad \mathrm{p}<0.001
\end{gathered}
$$

\section{The components of $Z_{S D}$ for the period 2000-2001}

In the same way we partitioned $\mathrm{k}_{\mathrm{T}}$ as the sum of the extinction coefficients that correspond to the variables that interfere with light penetration, $Z_{\mathrm{SD}}$ can also be partitioned. But, in this case $Z_{S D}$ presents exponential relationships with the considered variables (see Tables 2 and 4 and Figures 3 and 4). To avoid this effect of non-linearity we applied the inverse transformation, $1 / \mathrm{Z}_{\mathrm{SD}}$, which allows for an approximation by linear regression similar to the one used to partition $\mathrm{k}_{\mathrm{T}}$. In this case, we considered the following equation, 
Table 6. Values of the different components of light attenuation coefficient according to equation (7) for each sampled Julian day from May 2000 to December 2001. Calculated and measured light attenuation coefficients are indicated in the last two columns. Valores de los diferentes componentes del coeficiente de extinción de la luz calculados según la ecuación (7) para cada uno de los días julianos muestreados a lo largo del periodo de Mayo de 2000 a diciembre de 2001. En las dos últimas columnas se indica el valor del coeficiente de extinción calculado y medido.

\begin{tabular}{|c|c|c|c|c|c|c|c|c|}
\hline Year & Julian day & $\mathbf{k}_{\text {pom-detri }}$ & $\mathbf{k}_{\mathrm{chl}}$ & $\mathbf{k}_{\text {p-inor }}$ & $\mathbf{k}_{\text {p-phyto }}$ & $\mathbf{k}_{\mathbf{w}}$ & $\mathbf{k}_{\text {T-calc }}$ & $\mathbf{k}_{\mathbf{T}}$ \\
\hline 2000 & 131 & 0.48 & 0.68 & 0.06 & 0.21 & 0.09 & 1.51 & 1.44 \\
\hline 2000 & 172 & 0.25 & 0.39 & 0.06 & 0.12 & 0.09 & 0.91 & 0.86 \\
\hline 2000 & 200 & 0.26 & 0.36 & 0.06 & 0.11 & 0.09 & 0.88 & 0.88 \\
\hline 2000 & 221 & 0.38 & 0.47 & 0.01 & 0.15 & 0.09 & 1.09 & 0.87 \\
\hline 2000 & 263 & 0.30 & 1.01 & 0.01 & 0.32 & 0.09 & 1.71 & 1.21 \\
\hline 2000 & 292 & 0.10 & 0.68 & 0.02 & 0.21 & 0.09 & 1.09 & 0.94 \\
\hline 2000 & 319 & 0.10 & 0.17 & 0.03 & 0.05 & 0.09 & 0.43 & 0.68 \\
\hline 2000 & 347 & 0.13 & 0.50 & 0.06 & 0.16 & 0.09 & 0.93 & 0.91 \\
\hline 2001 & 44 & 0.13 & 0.06 & 0.00 & 0.02 & 0.09 & 0.3 & 0.55 \\
\hline 2001 & 101 & 0.07 & 0.03 & 0.03 & 0.01 & 0.09 & 0.23 & 0.49 \\
\hline 2001 & 130 & 0.31 & 0.09 & 0.05 & 0.03 & 0.09 & 0,57 & 0.75 \\
\hline 2001 & 157 & 0.57 & 0.31 & 0.08 & 0.10 & 0.09 & 1.14 & 1.09 \\
\hline 2001 & 199 & 0.34 & 0.33 & 0.04 & 0.10 & 0.09 & 0.90 & 0.70 \\
\hline 2001 & 234 & 0.19 & 0.76 & 0.02 & 0.24 & 0.09 & 1.28 & 0.86 \\
\hline 2001 & 262 & 0.21 & 0.30 & 0.04 & 0.10 & 0.09 & 0.73 & 0.94 \\
\hline 2001 & 290 & 0.25 & 0.69 & 0.04 & 0.22 & 0.09 & 1.28 & 1.01 \\
\hline 2001 & 318 & 0.15 & 0.24 & 0.02 & 0.08 & 0.09 & 0.58 & 0.80 \\
\hline 2001 & 346 & 0.15 & 0.07 & 0.01 & 0.02 & 0.09 & 0.34 & 0.93 \\
\hline
\end{tabular}

$$
\begin{gathered}
\mathrm{Z}_{\mathrm{SD}^{-1}=\mathrm{Z}_{\mathrm{SDw}}{ }^{-1}+\mathrm{Z}_{\mathrm{SDchl}}^{-1}+}+\mathrm{Z}_{\mathrm{SDpom}-\mathrm{detri}^{-1}}+\mathrm{Z}_{\mathrm{SDp} \text {-inor }}^{-1}+\mathrm{Z}_{\mathrm{SDp} \text {-phyto }}{ }^{-1}
\end{gathered}
$$

where the different terms of the sum correspond to the contribution of water, chlorophyll- $a$ concentration, organic detritic material, inorganic particles, and phytoplankton as particulate material to $\mathrm{Z}_{\mathrm{SD}^{-1}}$ in a similar way that in equation (3).

To calculate the different terms of the sum, we applied the lineal regression method used for $\mathrm{k}_{\mathrm{T}}$, estimating the independent variables in the same order. Therefore, the first lineal regression was estimated between $\mathrm{Z}_{\mathrm{SD}}{ }^{-1}$ and $\mathrm{SS}_{\mathrm{T}}$ (Fig.7), obtaining the following relation:

$$
\begin{aligned}
\mathrm{Z}_{\mathrm{SD}_{-} \mathrm{SST}^{-1}} & =7.14 \cdot 10^{-5}\left[\mathrm{SS}_{\mathrm{T}}\right]_{\left(\mathrm{mg} / \mathrm{m}^{3}\right)}+0.1563(10) \\
\mathrm{r}^{2} & =0.77, \mathrm{n}=18, \quad \mathrm{p}>0.001
\end{aligned}
$$

where 0.1563 represents the value of $\mathrm{Z}_{\mathrm{SDw}}{ }^{-1}+$ $Z_{\text {SDchl }^{-1}}$ in equation (9). In this case, the value of $\mathrm{Z}_{\mathrm{SDw}}{ }^{-1}$ was considered constant and equal to 0.0344 , which is the contribution equivalent to a $\mathrm{k}_{\mathrm{w}}$ $=0.09$, and it was estimated from the equation

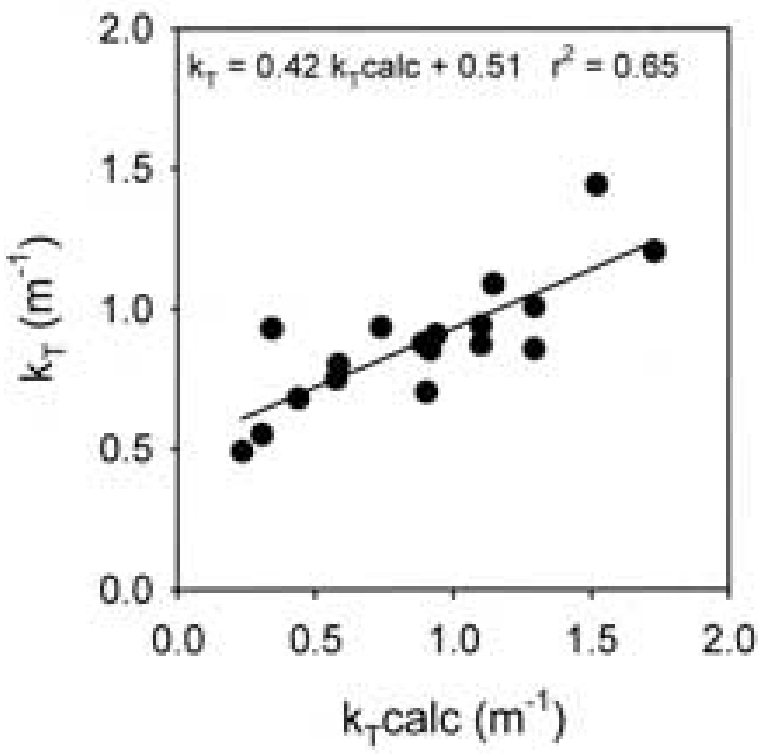

Figure 6. Relationship between the light attenuation coefficient calculated according to equation $(7)\left(\mathrm{k}_{\mathrm{Tcalc}}\right)$ and the measured value $\mathrm{k}_{\mathrm{T}}$. Relación entre el coeficiente de extinción de la luz calculado, $k_{T}$ calc, mediante la ecuación (7) y el valor medido $k_{T}$. 
$\mathrm{k}_{\mathrm{T}}=1.36 \mathrm{Z}_{\mathrm{SD}}{ }^{-0.806}$ that corresponds to the one found for Sau in this study. By subtracting the contribution of $\mathrm{Z}_{\mathrm{SDw}^{-1}}$ to the intersect value in equation (10), we calculated a value for $Z_{\mathrm{SDchl}}{ }^{-1}$ of 0.1219 , and after dividing it by the mean chlorophyll- $a$ concentration $\left(23.09 \mathrm{mg} / \mathrm{m}^{3}\right) \quad$ we can represent the contribution of each $\mathrm{mg} / \mathrm{L}$ of chlorophyll $a$ on $\mathrm{Z}_{\mathrm{SD}^{-1}}$. In this way, we can write $\mathrm{Z}_{\mathrm{SDchl}^{-1}}=0.00527_{\left(\mathrm{m}^{2} / \mathrm{mg}\right)}[\mathrm{chl} a]_{\left(\mathrm{mg} / \mathrm{m}^{3}\right)}$. After that, we repeated the procedure relating $Z_{\mathrm{SD}^{-1}}$ and the particulate organic material, considering $\mathrm{SS}_{\mathrm{pom}}=$ $\mathrm{SS}_{\mathrm{T}}-\mathrm{SS}_{\mathrm{p} \text {-inor }}$, to obtain the lineal regression (Fig. 7):

$$
\begin{gathered}
\mathrm{Z}_{\mathrm{SD}-\mathrm{pom}^{-1}=}=0.08 \cdot 10^{-5}\left[\mathrm{SS}_{\mathrm{pom}}\right]_{\left(\mathrm{mg} / \mathrm{m}^{3}\right)}+ \\
+0.2122 \\
\mathrm{r}^{2}=0.74, \quad \mathrm{n}=18, \quad \mathrm{p}>0.001
\end{gathered}
$$

in which 0.2122 corresponds to $\mathrm{Z}_{\mathrm{SDw}}{ }^{-1}+\mathrm{Z}_{\mathrm{SDchl}}{ }^{-1}$ $+Z_{\text {SDp-inor }}{ }^{-1}$, so $Z_{\text {SDp-inor }}{ }^{-1}=0.2122-0.1563=$ 0.0559 . Dividing $Z_{\mathrm{SDp} \text {-inor }}{ }^{-1}$ by the mean inorganic matter concentration $\left(1380 \mathrm{mg} / \mathrm{m}^{3}\right)$ we obtained that $\mathrm{Z}_{\mathrm{SDp}-\text { inor }}{ }^{-1}=4.05 \cdot 10^{-5}(\mathrm{~m} 2 / \mathrm{mg})\left[\mathrm{SS}_{\mathrm{p}}\right.$ $\left.{ }_{\text {inor }}\right]_{\left(\mathrm{mg} / \mathrm{m}^{3}\right)}$. Then, we can obtain the new partition for $\mathrm{Z}_{\mathrm{SD}^{-1}}$, taking into account that $\mathrm{SS}_{\mathrm{pom}-\text { detri }}=$ $\mathrm{SS}_{\mathrm{T}}-\mathrm{SS}_{\mathrm{p} \text {-inor }}-\mathrm{SS}_{\mathrm{p} \text {-phyto }}$ and therefore, the new lineal regression is,

$$
\begin{gathered}
\mathrm{Z}_{\mathrm{SD}-\text { pom.detri }}{ }^{-1}=1.22 \cdot 10^{-4} \\
{\left[\mathrm{SS}_{\text {pom-detri }}\right]_{\left(\mathrm{mg} / \mathrm{m}^{3}\right)}+0.2868} \\
\mathrm{r}^{2}=0.62, \mathrm{n}=18, \quad \mathrm{p}>0.001
\end{gathered}
$$

where the independent term is the value for $\mathrm{Z}_{\mathrm{SDw}}{ }^{-1}+\mathrm{Z}_{\mathrm{SDchl}}{ }^{-1}+\mathrm{Z}_{\mathrm{SDp} \text {-inor }}{ }^{-1}+\mathrm{Z}_{\mathrm{SDp} \text {-phyto }}{ }^{-1}$. Subtracting the intersect values in the equations (12) and (11) $0.2868-0.2122=0.0746$ we obtain $\mathrm{SS}_{\mathrm{p} \text {-phyto }}$ 's effect, and dividing it by the mean phytoplanktonic seston concentration, $2310 \mathrm{mg} / \mathrm{m}^{3}$ we obtain the new expression $3.23 \cdot 10^{-5}\left(\mathrm{~m}^{2} / \mathrm{mg}\right)[\mathrm{SSp}-\mathrm{phyto}]_{\left(\mathrm{mg} / \mathrm{m}^{3}\right)}$ that represents the contribution of each phytoplankton unit to $\mathrm{Z}_{\mathrm{SD}-1}$. Gathering now all the terms in which we partitioned $Z_{S D}{ }^{-1}$, we get the equation,

$$
\begin{gathered}
\mathrm{Z}_{\mathrm{SD}^{-1}}=1.22 \cdot 10^{-4}\left[\mathrm{SS}_{\mathrm{pom-detri}}\right]_{\left(\mathrm{mg} / \mathrm{m}^{3}\right)}+ \\
+5.27 \cdot 10^{-3}[\mathrm{chl} a]_{\left(\mathrm{mg} / \mathrm{m}^{3}\right)}+ \\
+4.05 \cdot 10^{-5}\left[\mathrm{SS}_{\mathrm{p}-\mathrm{inor}}\right]_{\left(\mathrm{mg} / \mathrm{m}^{3}\right)}^{+} \\
+3.23 \cdot 10^{-5}[\mathrm{SSp}-\mathrm{phyto}]_{\left(\mathrm{mg} / \mathrm{m}^{3}\right)}+0.0344
\end{gathered}
$$
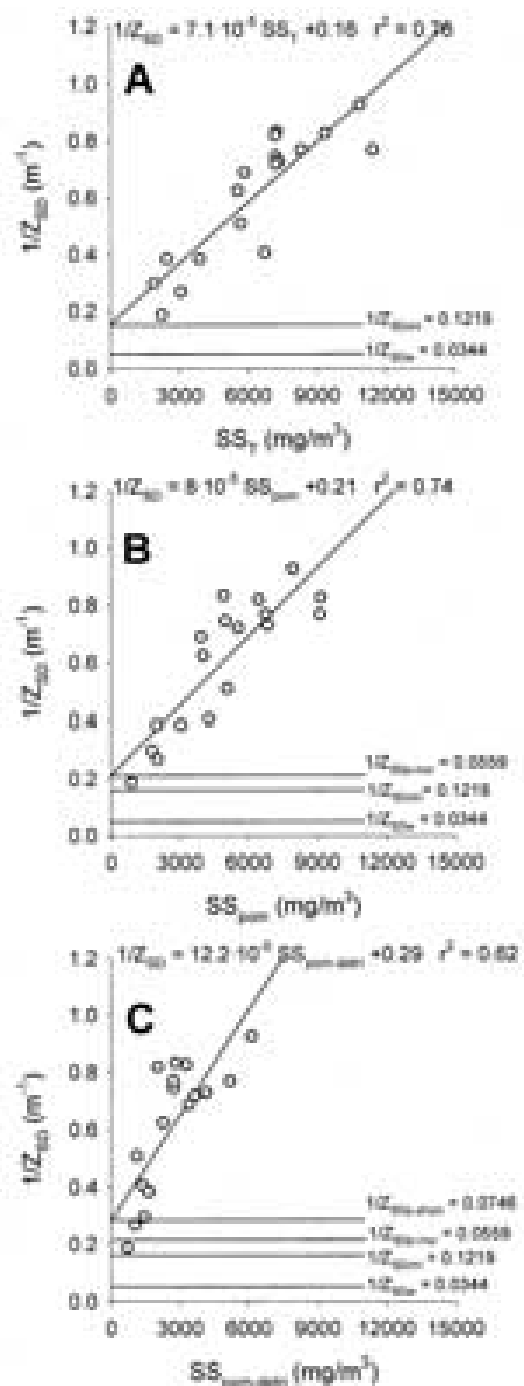

Figure 7. Partitioning of the inverse of Secchi depth using a multiple lineal regression method. In a first step (A) the effect of chlorophyll-a concentration $\left(1 / Z_{\text {SDchl }}\right)$ and of water $\left(1 / Z_{S D w}\right)$ is calculated, while in the intermediate step (B) the effect of the inorganic detritic matter $\left(1 / Z_{S D p-i n o r}\right)$ is included. Finally, $C$, the effect of the phytoplankton as particulate matter $\left(1 / Z_{S D p-p h y t o}\right)$ is also considered. In the last step, the final regression line relates the contribution of the organic detritic material $\left(1 / \mathrm{Z}_{\mathrm{SDpom} \text {-detri }}\right)$ to the inverse of the Secchi depth $\left(1 / \mathrm{Z}_{\mathrm{SD}}\right)$. Descomposición de la inversa de la profundidad de visión del disco de Secchi $1 / Z_{S D}$ mediante el método de regresión lineal multiple. En un primer paso, $A$, se obtiene el efecto de la concentración de clorofila a, $1 / Z_{S D c h}, y$ del agua, $1 / Z_{S D w}$, mientras en la fase intermedia, $B$, se añade el efecto del material inorgánico, $1 / Z_{S D \text {-inor }} y$, finalmente, $C$, se incluye el efecto del fitoplancton como material particulado, $1 / Z_{S D \text { phyto }}$ considerado como partícula de material orgánico. En este último caso la recta de regresión resultante establece la relación entre la concentración de material detrítico orgánico $\left(1 / Z_{S D p o m-d e t r i}\right)$ con la inversa de la profundidad de visión del disco de Secchi $\left(1\left(Z_{S D}\right)\right.$. 
Table 7. Values of the different components of Secchi depth according to equation (13) for each one of the sampled Julian days from May 2000 to December 2001. Calculated and measured Secchi depths are indicated in the last two columns. Valores de los diferentes componentes del disco de Secchi calculados según la ecuación (13) para cada uno de los días julianos muestreados a lo largo del periodo de Mayo de 2000 a diciembre de 2001. En las dos últimas columnas se indica el valor del la profundidad de visión del disco de Secchi calculado y medido.

\begin{tabular}{lc|ccccc|c|c}
\hline Year & Julian day & $\mathbf{Z}_{\text {SDpom-detri }}$ & $\mathbf{Z}_{\text {SDchl }}$ & $\mathbf{Z}_{\text {SDp-inor }}$ & $\mathbf{Z}_{\text {SDp-phyto }}$ & $\mathbf{Z}_{\text {SDw }}$ & $\mathbf{Z}_{\text {SD-calc }}$ & $\mathbf{Z}_{\text {SD }}$ \\
\hline 2000 & 131 & 0.53 & 0.17 & 0.08 & 0.11 & 0.03 & 0.91 \\
2000 & 172 & 0.79 & 0.29 & 0.21 & 0.18 & 0.08 & 1.30 \\
2000 & 200 & 0.81 & 0.26 & 0.22 & 0.16 & 0.08 & 1.54 \\
2000 & 221 & 0.81 & 0.23 & 0.03 & 0.14 & 0.06 & 1.54 \\
2000 & 263 & 0.45 & 0.35 & 0.01 & 0.21 & 0.04 & 1.27 \\
2000 & 292 & 0.48 & 0.74 & 0.09 & 0.45 & 0.12 & 1.06 \\
2000 & 319 & 1.53 & 0.63 & 0.51 & 0.39 & 0.42 & 3.48 \\
2000 & 347 & 0.56 & 0.51 & 0.33 & 0.31 & 0.11 & 1.83 \\
2001 & 44 & 2.96 & 0.32 & 0.07 & 0.20 & 0.59 & 4.13 \\
2001 & 101 & 2.37 & 0.28 & 1.47 & 0.17 & 0.94 & 5.24 \\
2001 & 130 & 1.27 & 0.09 & 0.24 & 0.05 & 0.11 & 1.72 \\
2001 & 157 & 0.67 & 0.09 & 0.11 & 0.05 & 0.03 & 0.45 \\
2001 & 199 & 0.89 & 0.20 & 0.14 & 0.12 & 0.07 & 0.95 \\
2001 & 234 & 0.52 & 0.49 & 0.06 & 0.30 & 0.07 & 1.42 \\
2001 & 262 & 1.01 & 0.34 & 0.23 & 0.21 & 0.13 & 1.46 \\
2001 & 290 & 0.56 & 0.36 & 0.11 & 0.22 & 0.06 & 1.92 \\
2001 & 318 & 1.33 & 0.50 & 0.22 & 0.31 & 0.23 & 1.35 \\
2001 & 346 & 2.46 & 0.26 & 0.23 & 0.016 & 0.43 & 1.39 \\
\hline
\end{tabular}

that is equivalent to equation (7) but with $\mathrm{Z}_{\mathrm{SD}}{ }^{-1}$ as a partitioned variable. If we invert the result again, we get an estimation of Secchi disk depth, $Z_{\text {SDcalc }}$, calculated from equation (13). Table 7 and figure 9 show the values of $Z_{\text {SDcalc }}$ for the 18 samplings performed between May 2000 and December 2001, as well as the contribution of each one of the variables that affects water transparency. Both variables, the measured and the estimated ones, are related by the equation (Fig. 8)

$$
\begin{gathered}
\mathrm{Z}_{\mathrm{SD}}=0.89 \mathrm{Z}_{\mathrm{SDcalc}}+016 \\
\mathrm{r}^{2}=0.9 \quad \mathrm{n}=18 \quad \mathrm{p}<0.001
\end{gathered}
$$

\section{DISCUSSION}

The use of $Z_{\mathrm{SD}}$ to estimate the trophic state of a lacustrine system is based on the double relationship: 1) chlorophyll- $a$ is a good estimator of phytoplankton biomass, and 2) $\mathrm{Z}_{\mathrm{SD}}$ is a good estimator of chlorophyll- $a$ concentration. The first one would only be true if we were to consider that the relationship between cell biomass and chlorophyll- $a$ concentration per cell is constant. According to Margalef (1983) chlorophyll$a$ concentration per cell varies between $0.5 \mathrm{pg}$ and $5 \mathrm{pg}$, with extreme values up to $50 \mathrm{pg}$ in deep water, long-lived phytoplankton. For this reason, this value is considered a good index of phytoplankton's physiological state. Edmonson (1980) also points out that cell size determines the level of chlorophyll packing, and that the effect on light absorption is lower when they are large and scattered than when they are small and grouped. Nevertheless, due to the lack of more accurate data, in this study we considered as an approximation, that the relation: phytoplankton dry weight / chlorophyll- $a$ concentration equals 100 (Reynolds, 1984, Philips et al, 1995, Effler et al, 2002) as a first approach to measure the effect of phytoplankton as a particle. For this reason, $\mathrm{k}_{\mathrm{p} \text {-phytp }}$ and $\mathrm{Z}_{\mathrm{SDp} \text {-phytol }}$ may have an implicit error in relation to other components of $\mathrm{k}_{\mathrm{T}}$ and $\mathrm{Z}_{\mathrm{SD}}$. Despite this, in no way we consider 


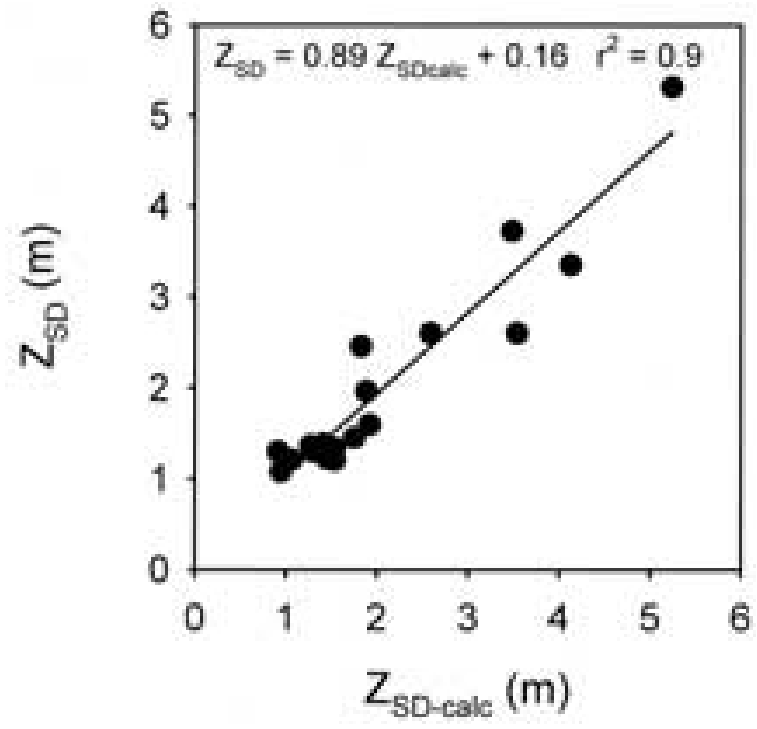

Figure 8. Relationship between Secchi depth calculated from the inverse function of equation (13) $\left(Z_{\text {SDcalc }}\right)$ and the measured Secchi depth $\left(\mathrm{Z}_{\mathrm{SD}}\right)$. Relación entre la profundidad de visión del disco de Secchi calculada a partir de la función inversa de la ecuación (13), $Z_{S D \text {-calc }}$ y el valor de esta misma variable medida $Z_{S D}$

that this error will affect our results significantly because chlorophyll- $a$ contribution to $\mathrm{k}_{\mathrm{T}}$ and $Z_{\mathrm{SD}}$ is relatively low in relation to the other factors that determine water transparency.

In many lakes and reservoirs, it is assumed that chlorophyll- $a$ concentration is one of the factors that determine water transparency, and $\mathrm{Z}_{\mathrm{SD}}$ routine measurements had been used to estimate the trophic state (Shapiro, 1975; Carlson, 1997). As we have just seen, in the Sau reservoir different forms of SST can affect water transparency, and in this case nor $Z_{\mathrm{SD}}$ or $\mathrm{k}_{\mathrm{T}}$ are good estimators of phytoplankton biomass. Spanish reservoirs are systems that receive high amounts of sediments transported from rivers with high erosion in their basins, or from the shores as a consequence of water level fluctuations (Margalef et al, 1976; Rull, 1984). Furthermore, Sau is located within a primarily calcareous basin were water alkalinity is high. Under these conditions carbonates can form colloids associated with the primary production peaks, or with the heating of superficial waters, increasing the influence of particulate material on light penetration. Another factor that must be considered is the presence of detritic organic material that is very important in eutrophic systems like Sau (Simek et al, 1999), because besides the autochthonous production they receive an elevated allochthonous organic load. Finally, it must be pointed out that in recent years the composition of the planktonic community has changed, with an important reduction of Cyanophyta colonies (Microcystis, Anabaenopsis), and an increase of Chlorophyta of medium or small size (Pediastrum, Scenedesmus, Oocystis, Sphaerocystis among others) that as particles have a much higher scattering effect on light.

The results obtained for Sau, highlight the joint effect of particles $\left(\mathrm{SS}_{\mathrm{T}}\right)$ on $\mathrm{Z}_{\mathrm{SD}}$ or $\mathrm{k}_{\mathrm{T}}$ and at the same time, they show the little importance of chlorophyll- $a$ concentration on this variables that measure light extinction.

If we perform this analysis for each year separately, the results vary among years. From 1995 to 1997 and in 2001 chlorophyll- $a$ concentration is indeed related to $Z_{S D}$, while from 1998 to 2000 there is no relationship. A possible explanation may be found in the different hydrological and morphological conditions in the reservoir during the period covered by this study. In this way, from 1995 to 1997 Sau reservoir had an elevated and rather constant mean annual volume, while 1998 to 2001 were dry years, and the reservoir had a lower volume with important fluctuations in water level associated to heavy rains. Under these conditions the input from the shores or from the shallow riverine zone of the reservoir increased, supplying not only clay sediments but detritic material as well.

In the Sau reservoir $\mathrm{Z}_{\mathrm{SD}}$ and $\mathrm{k}_{\mathrm{T}}$ are related by exponential equations (Table 1), even though there is a high interannual variability. The same problem arises when the product $\mathrm{Z}_{\mathrm{SD}} * \mathrm{k}_{\mathrm{T}}$ is used that, as we can see from Table 1, produce different results depending of the years which means that the contribution of each factor affecting the light climate is highly variable. The mean value for the whole period 1995-2001 was 1.78 , which is rather close to that estimated by 


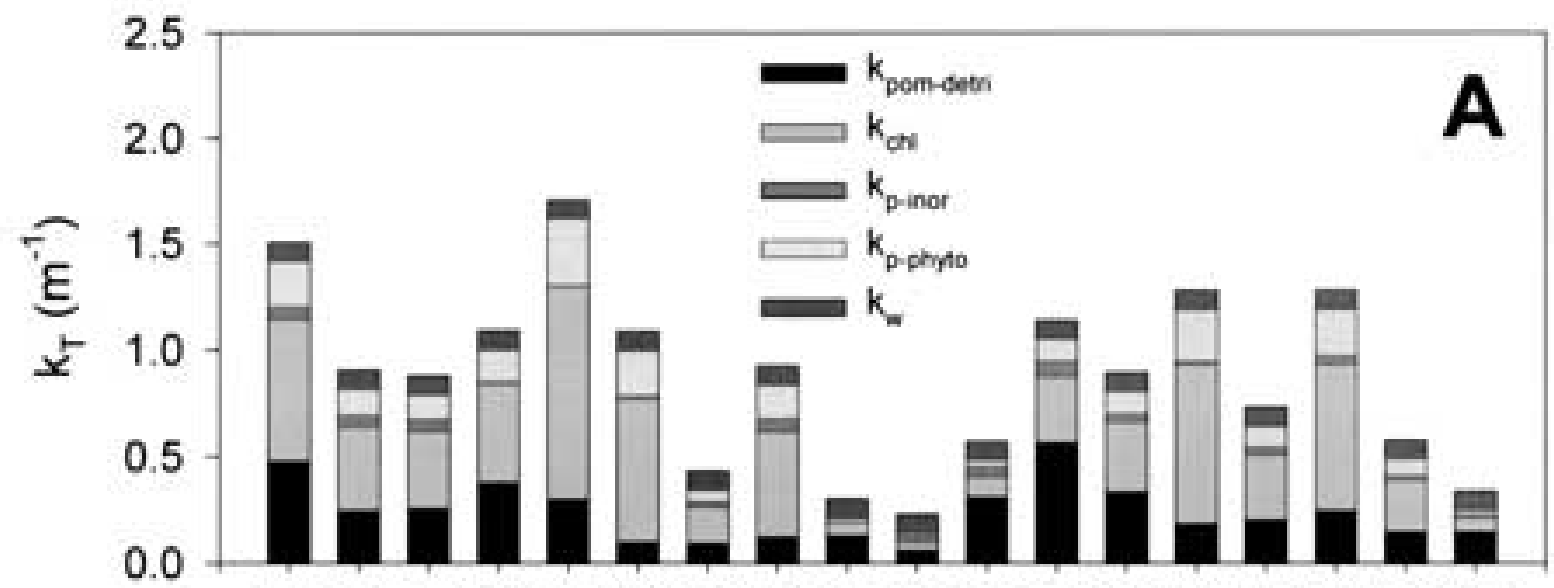

13117220022126329231934744101130157199234262290318346

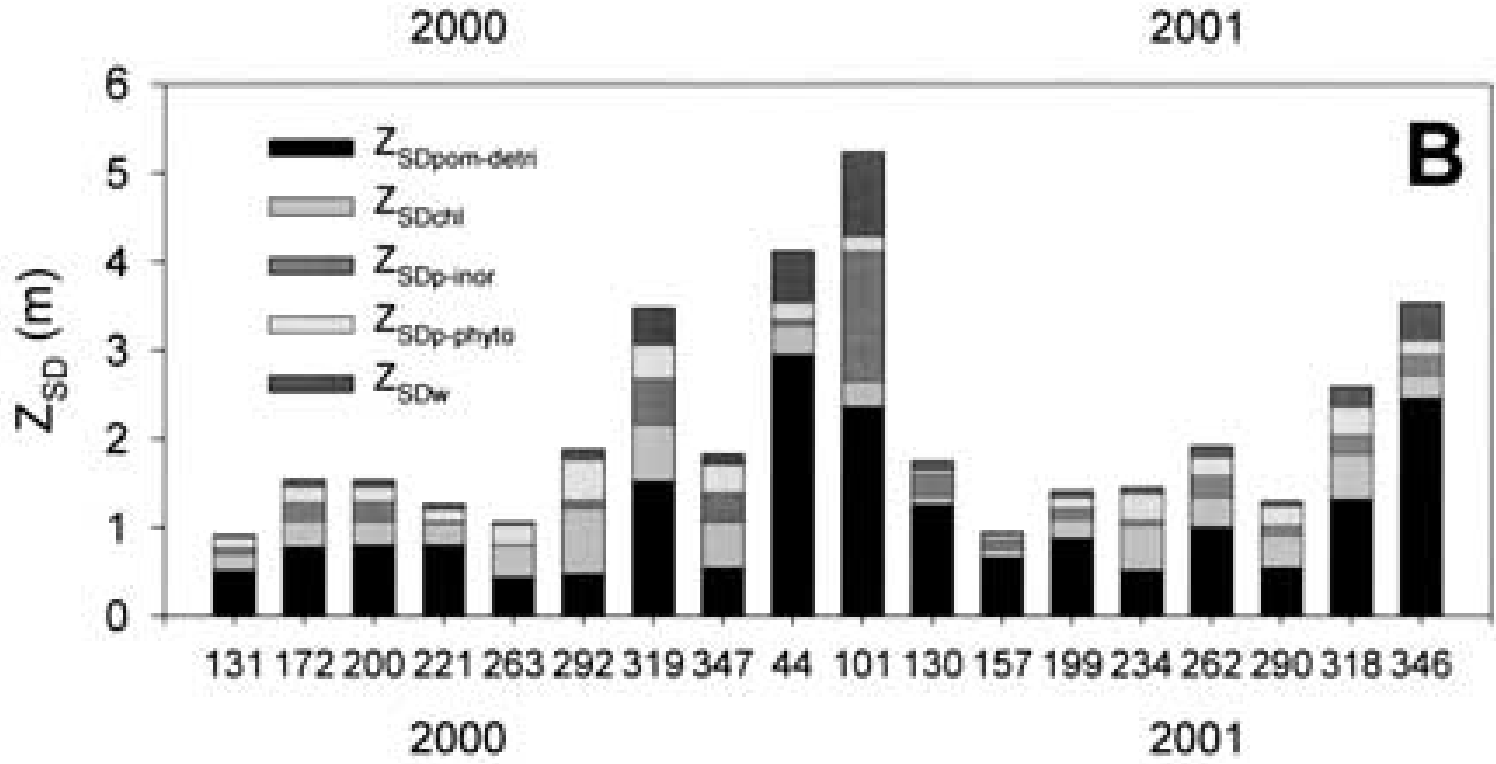

Figure 9. A) Partitioning of the light attenuation coefficient in the five components considered in this study according to equation (7). B) Contribution of each one of the components to the Secchi depth obtained from the inverse function of equation (13). A) Descomposición del coeficiente de extinción de la luz en los cinco componentes que se han considerado en este estudio y según la ecuación (7). B) Contribución de cada uno de los cinco componentes considerados en este estudio a la profundidad de visión del disco de Secchi, obtenidos mediante la función inversa de la ecuación (13).

Poole \& Atkins (1929) for marine ecosystems. However, as Koenings \& Edmunson (1991) pointed out, there is a high variability in the value of this product according to the type of lake considered, varying from values around 3 in humic lakes to 1.3 in turbid waters. These results do not agree with those found by Margalef et al. (1976). In this study of 100 Spanish reservoirs, the authors found that $\mathrm{Z}_{\mathrm{SD}} * \mathrm{k}_{\mathrm{T}}$ varies between
1.7 and 2.3, while in Sau reservoir this value ranged from 1.49 to 1.98 . This suggests that Spanish reservoirs in general and Sau reservoir in particular are systems of clear waters, according to Koenings \& Edmundson's (1991) classification. But this seems not to be true, because in this case chlorophyll- $a$ should show a better and clearer relation with $\mathrm{Z}_{\mathrm{SD}}$ and $\mathrm{k}_{\mathrm{T}}$. On the contrary, the partition of $\mathrm{k}_{\mathrm{T}}$ or $\mathrm{Z}_{\mathrm{SD}}$ shows that seston 
material or $\mathrm{SS}_{\mathrm{T}}$ is the one that contributes the most in shaping the type of light climate in Sau.

The presence of large amounts of particulate material seems to be the reason why chlorophyll- $a$ concentration in Sau reservoir shows, in general, no relationship with $Z_{S D}$ and $k_{T}$, although there is a high inter-annual variability. According to the transmittance theory of Tyler (1968) and Preisendorfer (1986), $\mathrm{Z}_{\mathrm{SD}}$ and $\mathrm{k}_{\mathrm{T}}$ do not measure exactly the same. According to these authors, $\mathrm{Z}_{\mathrm{SD}}$ would be more related to the extinction of directional radiation and $\mathrm{k}_{\mathrm{T}}$ to the diffuse radiation. But, as both variables tend to covary, this could explain why they are sometimes closely related. In the Sau reservoir, this covariance between $\mathrm{SS}_{\mathrm{T}}$ and chlorophyll- $a$ concentration does not exist, and this is one of the reasons why $\mathrm{SS}_{\mathrm{T}}$ shows a better correlation with $Z_{\mathrm{SD}}$ and $\mathrm{k}_{\mathrm{T}}$. During the period of this study, from May 2000 to December 2001, the influence of chlorophyll- $a$ concentration on $\mathrm{Z}_{\mathrm{SD}}$ and $\mathrm{k}_{\mathrm{T}}$ is very different on both variables (Fig. 9). Thus, the contribution of chlorophyll- $a$ on $\mathrm{k}_{\mathrm{T}}$ varies between $14 \%$ and $61.2 \%$ while the contribution on $\mathrm{Z}_{\mathrm{SD}}$ varies between $4.9 \%$ and $39.2 \%$. On the other hand, when the contribution of the detritic material is analysed, values ranged from $11 \%$ to $63.6 \%$ for $\mathrm{k}_{\mathrm{T}}$ and from $30.3 \%$ and $86 \%$ for $Z_{S D}$. These results confirm that in the Sau reservoir the diffuse radiation predominates and that, under these conditions, $Z_{\mathrm{SD}}$ represents a much more accurate estimation of both water transparency and particulate matter concentration. This low contribution of chlorophyll- $a$ to $Z_{\mathrm{SD}}$ and $\mathrm{k}_{\mathrm{T}}$ should warn about the generalized use of $Z_{\mathrm{SD}}$ to estimate reservoirs' trophic state.

The results obtained for Sau, show that the contribution of chlorophyll- $a$ concentration to light penetration in water is not always significant in relation to $Z_{\mathrm{SD}}$ and $\mathrm{k}_{\mathrm{T}}$. When this happens, to identify those variables that contribute to light climate is important in order to explain the external causes, fluctuations in water level, heavy rains, dry periods, that influence light penetration, and that are not only due to phytoplankton concentration and the amount of solar radiation that reaches the surface of a reservoir. The abovementioned factors, which do not follow patterns of seasonal variation, can be one of the reasons for the high interannual variability observed in many Mediterranean reservoirs.

\section{ACKNOWLEDGEMENTS}

The authors wish to thank M. A. Gallegos for their assistance with laboratory and field work. The limnological study of the Sau reservoir is part of a long-term study supported by Aigües Ter-Llobregat (ATLL). This project has been partially supported by the Ministerio de Ciencia y Tecnología (Project REN2001-2185-CO2O2). Two authors (Rafael Marcé and Luciano Caputo) are grantees of the Ministerio de Ciencia y Tecnología. The contribution of the Comisión Interministerial de Ciencia y Tecnología (CIRIT) of the Generalitat de Catalunya by means of the grant 2001SGR104 is greatly appreciated.

\section{BIBLIOGRAPHY}

APHA (AMERICAN PUBLIC HEALTH ASSOCIATION). 1992. Standard Methods for the Examination of Water and Wastewater. $18^{\text {th }}$ ed. American Public Health Association.

BLEIKER, W \& F SCHANZ. 1997. Light climate as the key factor controlling the spring dynamics of phytoplankton in Lake Zürich. Aquatic Sciences, 59: 135-157.

CAPBLANCQ, J., P. LAVANDIER et M. PETIT. 1994. Production du phytoplancton et du bactériòplancton dans le lac de retenue de Pareloup. Hydroécol. Appl., 6: 153-171.

CARLSON, R. E. 1977. A trophic state index for lakes. Limnol. Oceanogr., 22: 361-369.

EDMONDSON, W. T. 1972. Nutrients and phytoplankton in Lake Washington. Am. Soc. Limnol. Oceanogr. Spec. Symp., 1: 172-193.

EDMONDSON, W. T. 1980. Sechi disk and chlorophyll. Limnol. Oceanogr., 25: 378-379.

EFFLER, S. W., M. G. PERKINS, N. OHRAZDA, D. A. MATTHEWS, R. GELDA, F. PENG, D. L. 
JOHNSON \& C. L. STEPHCZUK. 2002. Tripton, transparency and light penetration in seven New York reservoirs. Hydrobiologia, 468: 213-232.

JASSBY, A. D., C. R. GOLDMAN, J. E. REUTER \& R. C. RICHARDS. 1999. Origins and scale dependence of temporal variability in the transparency of Lake Tahoe, California-Nevada. Limnol. Oceanogr. 44: 282-294.

JEFFREY, S. W. \& G. F. HUMPHREY. 1975. New spectrophotometric equations for determining chlorophylls a, b, c1 and c2 in higher plants, algae and natural phytoplankton. Biochem. Physiol. Pflanzen, 168: 191-194.

KALFF, J. 2002. Limnology. Inland Water Ecosystems. Prentice Hall.

KIRK, J. T. O. 1994. Light and photosynthesis in aquatic ecosystems. $2^{\text {nd }}$ Ed. Cambridge University Press.

KOENINGS, J. P., J. A. EDMUNDSON. 1991. Secchi disk and photometer estimates of light regimes in Alaskan lakes: Effects of yellow color and turbidity. Limnol. Oceanogr., 36: 91-105.

LAPIERRE, J. D. \& J. A. R. EDMUNDSON. 2000. Limnology of two lake systems of Katmai National Park and Preserve, Alaska: Part II. Light penetration and Secchi Depth. Hydrobiologia, 418: 209216.

LORENZEN, M. W. 1980. Use of chlorophyll-Secchi disk relationships. Limnol. Oceanogr., 25: 371372.

LATHROP, R.C., S. R. CARPENTER \& L. G. RUDSTAM. 1996. Water clarity in Lake Mendota since 1990: responses to differing levels of nutrients and herbivory. Can. J. Fish. Aquat. Sci., 53: 2250-2261.

LIND, O. T. 1986. The effect of non-algal turbidity on the relationship of Secchi depth to chlorophyll $a$. Hydrobiologia, 140: 27-35.

LIND, O. T., R. DOYLE, D. S. VODOPICH, B. G. TROTTER, J. G. LIMÓN, L. DÁVALOS-LIND. 1992. Clay turbidity: Regulation of phytoplankton production in a large, nutrient-rich tropical lake. Limnol. Oaceanogr., 37: 549-565.

MARGALEF, R. 1983. Limnología. Ed. Omega.

MARGALEF, R., D. PLANAS, D, ARMENGOL, A. VIDAL, N. PRAT, A. GUISET, J. TOJA Y M. ESTRADA. Limnología de los embalses españoles. Dirección Gral. Obras Hiráulicas. MOPU. Madrid.

MEGARD, R. O. 2000. Diagnosis of light attenuance with Secchi disks. Arch. Hydrobiol. Spec. Issues Advanc. Limnol., 55: 169-178.

MEGARD, R. O., J. C. SETTLES, H. A. BOYER \&
W. S. COMBS, JR. 1980. Light, Secchi discs and trophic states. Limnol. Oceanogr., 25: 373-377.

MORALES BAQUERO, R., J. M. CONDE PORCUNA, C. PÉREZ MARTÍNEZ \& L. CRUZ PIZARRO. 1991. Vertical light attenuation in four reservoirs of genil river (Granada, Spain). Commission Internationale Des Grands Narrages, 64 : 137-148. OGLESBY, R. T. \& R. SCHAFFNER. 1975. The response of lakes to phosphorus. In: Nitrogen and phosphorus food production, waste and the environment. K.S. Porter (Ed.): 23-57. Ann Arbor Sci.

PHLIPS, E. J., F. J. ALDRIDGE, C. L. SCHELSKE \& T. L. CRISMAN. 1995. Relationships between light availability chlorophyll $a$, and tripton in a large, shallow subtropical lake. Limnol. Oceanogr., 40: 416-421.

PHLIPS, E. J., M. CICHRA, K. HAVENS, C. HANLON, S. BADYLAK, B. RUETER, M. RANDALL, \& P. HANSEN. 1997. Relationships between phytoplankton dynamics and the availability of light and nutrients in a shallow sub-tropical lake. Journal of Plankton Research, 19: 319-342.

POOLE, H. H. \& W. R. ATKINS. 1929. Photo-electric measurements of submarine illumination throughout the year. J. Mar. Biol. Assoc. U.K., 16: 297-324.

PREISENDORFER, R. W. 1986. Secchi disc science: Visual optics of natural waters. Limnol. Oceanogr., 31: 909-926.

REYNOLDS, C.S. 1984. The Ecology of Freshwater Phytoplankton. Cambridge Univ. Press.

RULL, V., T. VEGAS \& J. NAVARRO. 1984. Extinción de la luz en los embalses españoles. Relaciones con la concentración de clorofila y las partículas en suspensión. Oecologia Aquatica, 7: 25-36.

SHAPIRO, J; J. B. LUNDQUIST, R. E. CARLSON. 1975. Involving the public in limnology. An approach to communication. Verh. Internat. Verein. Limnol., 19: 866-874.

SIMEK, K., J. ARMENGOL, M. COMERMA, J. C. GARCIA, T. H. CHRZANOWSKI, P. KOJECKA, M. MACEK, J. REDOMA \& V. STRASKRABOVA. 1999. Impacts of protistan grazing on bacterial dynamics and composition in reservoirs of different trophy. In: Theoretical Reservoir Ecology and its Implications. J. G. Tundisi \& M. Straskraba (Eds.): 267-282. International Institute of Ecology. Brazilian Academy of Sciences \& Backhuys Publishers.

TYLER, J. E. 1968. The Secchi disc. Limnol. Oceanog., 13: 1-6.

WETZEL, R.G. 1983. Limnology, 2nd Ed. Saunders Coll. 